\title{
Immunohistochemical determination of the appropriate anti-hTERT antibodies for in situ detection of telomerase activity in frozen sections of head and neck squamous cell carcinomas and tumor margin tissues
}

\author{
EVA-MARIA FABRICIUS ${ }^{1}$, UTE KRUSE-BOITSCHENKO ${ }^{1}$, REEM KHOURY ${ }^{1}$, \\ GUSTAV-PAUL WILDNER ${ }^{2}$, JAN-DIRK RAGUSE ${ }^{1}$ and MARTIN KLEIN ${ }^{1}$ \\ ${ }^{1}$ Clinic for Oral and Maxillofacial Surgery, Campus Virchow Hospital and ${ }^{2}$ formerly Department of Pathology, \\ Robert-Rössle-Clinic, Campus Berlin-Buch, Charité-Universitätsmedizin, Berlin, Germany
}

Received January 23, 2009; Accepted February 23, 2009

DOI: 10.3892/ijo_00000254

\begin{abstract}
In previous studies we demonstrated telomerase activity in frozen tissue from head and neck squamous cell carcinoma (HNSCC) and their tumor-free tumor margins. In the present study frozen sections from the same tissues were examined for in situ presence of hTERT. In preliminary investigations we established that the most suitable method of tissue preparation was fixation in acetone and methanol followed by steaming and visualization by APAAP. Most of the assays involved eleven anti-hTERT antibodies and were supplemented with the inclusion of antibodies Ki-67, antinucleolin and CD45. hTERT expression was investigated in the tissues of 61 patients with HNSCC and 37 patients without tumor. Semi-quantitative immunoreactive scores were correlated with telomerase activity. We examined the prognostic significance of hTERT expression with Kaplan-Meier curves and tested the immunological specificity of the antibodies by
\end{abstract}

Correspondence to: Dr Eva-Maria Fabricius, Clinic for Oral and Maxillofacial Surgery, Campus Virchow Hospital, CharitéUniversitätsmedizin, Augustenburger Platz 1, D-13353 Berlin, Germany

E-mail: eva-maria.fabricius@charite.de

Abbreviations: aa, amino acid; Ab, antibody; APAAP, alkaline phosphatase anti-alkaline phosphatase; bb, base pairs; EDTA, ethylene diamine tetraacetic acid; ELISA, enzyme-linked immunosorbent assay; HNSCC, head and neck squamous cell carcinoma; hTERT, human telomerase reverse transcriptase; IRS, immunoreactive scores; MRD, minimal residual disease; PCNA, proliferating cell nuclear antigen; PCR, polymerase chain reaction; RT-PCR, reverse transcriptions-PCR; TA, telomerase activity; TBS, Tris-buffered saline; TRAP, telomeric repeat amplification protocol; TRS, target retrieval solution

Key words: head and neck squamous cell carcinoma, tumor margin, telomerase, human telomerase reverse transcriptase, immunohistochemistry, frozen sections, prognosis immunoabsorption with two hTERT peptides and a nucleolin peptide. Nuclear staining of satisfactory distribution and intensity was achieved in seven anti-hTERT antibodies both in the carcinomas and in the squamous epithelia of the tumor resection margins and in the control tissues. Proof of hTERT did not differ from telomerase activity. The telomerase activity demonstrated in tumor-free resection margins and in control tissues did, however, correlate with lymphocytic-monocytic infiltration (CD45 expression). This telomerase activity might be related to nuclear hTERT expression in the squamous epithelium, given that the hTERT score values in the connective tissue tended to be negative. The prognostic significance of hTERT expression demonstrated on paraffin sections from different tumor localizations was not confirmed for the frozen sections of patients with HNSCC. The hTERT specificity of the monoclonal NCL-L-hTERT, whose use as an antibody against hTERT has been questioned, was reexamined with immunohistochemical methods, but the intensity of its immunoabsorption with the nucleolin peptide did not exceed that observed in the other anti-hTERT antibodies.

\section{Introduction}

Squamous cell carcinomas in the head and neck region (HNSCC) are characterized by a high rate of loco-regional recurrence and secondary tumors. An important cause of this is field cancerization $(1,2)$ in the area around the tumor. In order to identify patients at risk, extensive studies have examined the specific biology of the invading tumor front and marginal tissue, and trials are in progress to identify the molecular or immunohistochemical markers best suited for characterizing tumor-free margin tissue (3-9).

Telomerase activity was demonstrated in the tumor and in the tumor margin of head and neck squamous cell carcinomas (10-12). In earlier studies we looked for a difference in telomerase activity between tumor margin tissue of head and neck tumors, the tumor itself and control tissue (13-15). We demonstrated telomerase activity in $30 \%$ of 20 tumor-free marginal tissue specimens and in 20 tumor distant tissue 
Table I. Characterization of the 61 patients with a head and neck squamous cell carcinoma (HNSCC).

\begin{tabular}{|c|c|c|c|c|c|c|c|c|c|c|c|}
\hline & & & & & & & & & & & \\
\hline & & & & & & No. & Sex/Age ${ }^{a}$ & Localization & TNM & $\mathrm{S}$ & G \\
\hline No. & Sex/Age ${ }^{a}$ & Localization & TNM & $\mathrm{S}$ & $\mathrm{G}$ & 51 & $\mathrm{M} / 52$ & Tongue & TxN0M0 & $\mathrm{x}$ & 1 \\
\hline 1 & $\mathrm{M} / 39$ & Floor of mouth & T3N1M0 & 3 & 3 & 52 & $\mathrm{~F} / 64$ & Tongue & $\mathrm{T} 2 \mathrm{~N} 2 \mathrm{cM} 0$ & $4 a$ & 3 \\
\hline 2 & $\mathrm{M} / 52$ & Floor of mouth & T4N0M0 & $4 \mathrm{a}$ & 3 & 53 & $\mathrm{M} / 52$ & Tonsil, palate & $\mathrm{T} 2 \mathrm{~N} 2 \mathrm{M} 1$ & $4 c$ & 3 \\
\hline 3 & $\mathrm{M} / 59$ & Floor of mouth & T1N2M0 & $4 \mathrm{a}$ & 2 & 54 & $\mathrm{M} / 69$ & Tonsil, palate & T4N3Mx & $4 b$ & 2 \\
\hline 4 & $\mathrm{M} / 50$ & Floor of mouth & T4N1Mx & $4 a$ & 2 & 55 & $\mathrm{~F} / 71$ & Oral mucosa & $\mathrm{T} 2 \mathrm{~N} 2 \mathrm{M} 0$ & $4 a$ & 2 \\
\hline 5 & $\mathrm{M} / 58$ & Floor of mouth & T3N2M0 & $4 a$ & 3 & 56 & $\mathrm{~F} / 59$ & Lips & T2N0M0 & 2 & 2 \\
\hline 6 & $\mathrm{M} / 62$ & Floor of mouth & T2N2M0 & $4 a$ & 3 & 57 & $\mathrm{M} / 74$ & Lips & T2N0M0 & 2 & 2 \\
\hline 7 & $\mathrm{M} / 50$ & Floor of mouth & T4N1M0 & $4 a$ & 3 & 58 & $\mathrm{M} / 66$ & Lips & T1NxMx & 1 & 2 \\
\hline 8 & $\mathrm{M} / 52$ & Floor of mouth & $\mathrm{T} 4 \mathrm{~N} 2 \mathrm{cM} 0$ & $4 b$ & 1 & 59 & $\mathrm{~F} / 75$ & Lips & T4NxMx & $4 a$ & 2 \\
\hline 9 & $\mathrm{M} / 63$ & Floor of mouth & T2N0M0 & 2 & 2 & 60 & $\mathrm{M} / 63$ & Lips & T2N2M0 & $4 \mathrm{a}$ & 3 \\
\hline 10 & $\mathrm{M} / 53$ & Floor of mouth & T1N0M0 & 1 & 2 & 61 & $\mathrm{M} / 90$ & Ear & T1N0M0 & 1 & 1 \\
\hline
\end{tabular}

12 F/65 Floor of mouth tongue

$13 \mathrm{M} / 55$ Floor of mouth tongue

$14 \mathrm{M} / 55 \quad$ Floor of mouth tongue

$15 \mathrm{M} / 57 \quad$ Floor of mouth tongue

$16 \mathrm{M} / 60 \quad$ Floor of mouth tongue

$17 \mathrm{M} / 49$ Floor of mouth tongue

$18 \mathrm{M} / 46 \quad$ Floor of mouth tongue

$19 \mathrm{M} / 51$ Floor of mouth mandible

$20 \mathrm{M} / 58$ Tongue

$21 \mathrm{M} / 55$ Tonsil, palate

$22 \mathrm{M} / 81$ Tonsil, palate

$23 \mathrm{M} / 58$ Tonsil, palate

$24 \mathrm{M} / 50 \quad$ Oral mucosa

$25 \mathrm{M} / 53$ Oral mucosa

$26 \mathrm{M} / 66$ Oral mucosa

$27 \mathrm{M} / 55$ Oral mucosa

$28 \mathrm{M} / 58$ Oral mucosa

$29 \mathrm{M} / 59$ Oral mucosa

30 F/61 Oral mucosa

31 F/76 Buccal mucosa

32 F/71 Buccal mucosa

$33 \mathrm{M} / 57$ Buccal mucosa

$34 \mathrm{M} / 75 \quad$ Lips

35 F/89 Nose

$36 \mathrm{M} / 68 \quad$ Ear

$37 \mathrm{M} / 64 \quad$ Ear

$38 \mathrm{M} / 65 \quad$ Ear

$39 \mathrm{M} / 57 \quad$ Ear

$40 \quad$ M/93 Scalp

$41 \mathrm{M} / 49$ Floor of mouth

$42 \mathrm{M} / 47 \quad$ Floor of mouth

$43 \mathrm{M} / 53$ Floor of mouth

$44 \mathrm{M} / 52$ Floor of mouth

$45 \mathrm{M} / 42$ Floor of mouth tongue

$46 \mathrm{M} / 53 \quad$ Floor of mouth tongue

$47 \mathrm{M} / 53 \quad$ Floor of mouth tongue

$48 \mathrm{M} / 45$ Tongue

$49 \mathrm{~F} / 51 \quad$ Tongue

$50 \mathrm{M} / 50$ Tongue

Table I. Continued.

Sex: M, male; F, female; a Age at tissue harvesting in years; S, staging; $\mathrm{G}$, grading; $\mathrm{x}$, unknown, see TNM classification (24).

T4NOM0 4a 3

T4N0Mx 4a 3

T4N0M0 4a 2

T4N1M0 4a 3

T2NOM0 22

T4N0Mx 4a 3

T2NOMO 22

T2N1M0 32

T2N1M0 33

T1N3M0 4b 2

T4N3Mx 4b 3

T2N2bM0 4a 2

T4NxMx 4a 2

T1N0M0 13

T1N1M0 33

T4N3M1 4c 2

T4N2cM0 4a 2

T4N0M0 4a 2

T3N1M0 32

T3NOM0 $3 \quad 1$

T2N1M0 32

T2NOM0 22

T2NOM0 22

T4N0M0 4a 2

T4N0M0 4a 2

T4N1M0 4a 2

T4N1M0 4a 3

T1NOM0 12

T2N1M0 32

T4NOMO 4a 2

T1NOM0 12

T1N0M0 12

T4N2cM0 4a 2

T2NOMO 23

T1N0M0 12

T3N2M0 4a 3

T3N2M0 4a 3

T1NOM0 13 specimens. Proof of telomerase using PCR yields no information about telomerase expression in individual cells, but immunohistochemistry is well suited for the in situ presentation of telomerase positive cells, providing that suitable antibodies are available. This prompted us in the present study to subject the same frozen tissues in which we had demonstrated telomerase activity by PCR-ELISA [TRAP-protocol, Kim et al (16)] to an immunohistochemical investigation to find out specifically which cells express the catalytic protein subunit of telomerase, human telomerase reverse transcriptase (hTERT).

When we started, the only immunohistochemical hTERT results which had been published related to paraffin sections or cells embedded in paraffin (17-22). The first challenge was therefore to determine which commercially available antibodies and which method would yield the best nuclear presentation of hTERT in frozen sections. At the same time we wanted to investigate whether proof of hTERT in resection margins was of prognostic relevance.

After we had completed the experimental phase of our study, Wu et al (23) reported that the monoclonal antibody NCL-L-hTERT, which we had considered particularly well suited to our purposes, reacted primarily to nucleolin. This prompted us to carry out additional experiments before interpreting our results and to include the antibodies studied by Wu et al (23) in our study.

\section{Patients and methods}

Patients and tumor tissue samples. All tissues examined were taken from the head and neck area with previous consent of the patients in our clinic in the context of diagnostics and therapy. Ninety-six squamous cell carcinoma specimens (40 tumor center tissue specimens with carcinoma and possibly squamous epithelia, 38 tumor-free margin tissues with squamous epithelia and 18 tumor-free tumor-distant tissues with squamous epithelia) were collected from 61 patients in the period from 1994 to 1997 (Table I). 
The entire frozen section series was examined by a tumor pathologist with conventional hemalaun-eosin staining to ensure that carcinoma was present in all tumor center tissue specimens and that the tumor margins and tumor distant tissues were all tumor-free.

We examined tissue of different locations from 61 patients with HNSCC: 51 males (84\%) aged 58+11 years and 10 female patients $(16 \%)$ aged $68 \pm 11$ years. Forty-eight patients had oral and 13 had extraoral squamous cell carcinomas. Patient age refers to age at the time point of tissue removal. TNM classification (24) and degree of differentiation were established by the Institute of Pathology in our hospital. In the tumor center we evaluated the carcinoma and any squamous epithelium present. In the tumor-free margin and tumor distant tissues we evaluated the squamous epithelium.

Patients and control tissue specimens. For a more critical evaluation of hTERT expression in carcinoma tissues we examined oral and extraoral control tissue from different locations in 37 patients without tumor from our clinic in the period from 1994 to 2004: 20 males aged 36 \pm 19 years and 17 females aged $40 \pm 20$ years. In the control tissue sections we evaluated hTERT in squamous epithelium. We examined 23 oral (2x palate, 5x gingiva, 9x oral mucosa, $2 x$ oropharynx, $2 \mathrm{x}$ cheek and $3 \mathrm{x}$ margins of tongue) and 14 extraoral tissues (1x eye, $2 \mathrm{x}$ skin, $1 \mathrm{x}$ lips, $3 \mathrm{x}$ nose, $4 \mathrm{x}$ ear, $2 \mathrm{x}$ scalp and $1 \mathrm{x}$ forehead). The tissues were taken with the patients' consent in the context of therapy.

Antibodies and experiments carried out to optimize frozen section preparation of squamous cell carcinomas (Table II). We used the frozen sections from squamous cell carcinomas in which we had previously demonstrated telomerase activity in PCR-ELISA (13-15). For optimal immunohistochemical results we used the four commercially available anti-hTERT antibodies, the three polyclonal rabbit antibodies $[\mathrm{Ab} 1, \mathrm{Ab} 2$ and $\mathrm{Ab} 4$ (Table II)] and one monoclonal murine antibody [Ab 3 (Table II)]. These were the antibodies used by Hiyama et al (17), Poremba et al (18-20), Yan et al (21) and Park et al (22) for paraffin sections and cell cultures embedded in paraffin to determine hTERT with the EnVision demonstration system (DakoCytomation, Denmark). Using the same preparatory processing and EnVision we achieved only cytoplasmic staining in the squamous cell carcinomas and only in those epithelial and carcinoma cells with a more or less stained background. We therefore reverted to APAAP (25-28), which had proved successful in earlier immunohistochemical examinations. The purpose was to achieve nuclear and/or nucleolar presentation of hTERT with commercial antibodies. Fixation for $9 \mathrm{~min}$ in methanol and subsequently $1 \mathrm{~min}$ of aceton fixation at $-20^{\circ} \mathrm{C}$ proved the most successful method, more suitable than acetone alone, methanol alone or $4 \%$ paraformaldehyde at $4^{\circ} \mathrm{C}$ or $-20^{\circ} \mathrm{C}$. Nonetheless, additional pretreatment of the frozen sections was necessary. The best nuclear presentation was achieved when the frozen sections were pretreated for $30 \mathrm{~min}$ in a steamer (Braun Multi Gourmet Plus FS20, Kronberg, Germany) in TRS-Puffer S1699 (Dako Cytomation) $\mathrm{pH}$ 6.1. Results of pretreatment in the autoclave or microwave in various buffers with and without Tween and with and without EDTA were less successful. This procedure was maintained throughout the study and with all newly acquired anti-hTERT antibodies which became commercially available (Ab 5 to Ab 11) (Table II).

The results of immunohistochemistry were compared with control antibodies: a monoclonal mouse anti-human Ab 12 against Ki-67, a polyclonal rabbit antibody Ab 13 against nucleolin and a monoclonal mouse Ab 14 against leukocyte common antigen (Table II). Ki-67 was used to prove proliferation and for better recognition of carcinomas in the tiny frozen sections; CD45 for better visualization of lymphocyte mononuclear infiltration. After the monoclonal anti-hTERT antibody (clone 44F12, code NCL-hTERT, Ab 3) was described in the study by $\mathrm{Wu}$ et al (23) as an antibody against nucleolin, we expanded our investigation and incorporated an anti-nucleolin antibody (Ab 13) to clarify this issue.

Immunohistochemistry and immunoreactive score values (IRS). All incubation steps taken in the immunohistochemical staining process were performed in a humidified chamber. To block non-specific reactions we incubated sections at room temperature for 20 min with the ready-made X0909 blocking buffer (DakoCytomation). Between each step the sections were rinsed thoroughly three times in TBS buffer, pH 7.6 (Trisbuffered saline, concentrated 10X, S3001 DakoCytomation; with $\mathrm{pH}$ of dilution at 7.6). All antibodies were diluted in S2022 (DakoCytomation, ready to use). We determined the optimal dilution for each antibody in accordance with the product data sheets. Antibodies were incubated for $60 \mathrm{~min}$ at $37^{\circ} \mathrm{C}$ in the drying oven and then for $30 \mathrm{~min}$ at room temperature. In the case of some antibodies only a limited number of tissues were stained.

The alkaline phosphatase anti-alkaline phosphatase [APAAP (25)] used to detect the antigen antibody reaction was carried out as follows: the two bridge antibodies were incubated at room temperature at 1:40 (diluted in antibody dilution plus $5 \%$ AB serum by Biotest AG, Dreieich, Cat. $805135 /$ Germany). For sections with polyclonal primary antibodies (for $\mathrm{Ab} 1, \mathrm{Ab} 2, \mathrm{Ab} 4$ to $\mathrm{Ab} 9, \mathrm{Ab} 13$ ) monoclonal mouse anti-rabbit bridge antibodies (DakoCytomation M0737) were applied and for sections with monoclonal antibodies (for $\mathrm{Ab} 3, \mathrm{Ab} 10, \mathrm{Ab} 11, \mathrm{Ab} 12, \mathrm{Ab} 14)$ polyclonal rabbit anti-mouse bridge antibodies (DakoCytomation Z0259) were used. Sections were then incubated for $40 \mathrm{~min}$ with the monoclonal APAAP complex (DakoCytomation D0651), diluted 1:100 in antibody dilution plus $5 \%$ inactivated fetal calf serum (FKS, Biochrom AG, Berlin, S0115, Germany). Substrate development lasted approximately $20 \mathrm{~min}$ (gauged by visual judgment) with DakoCytomation K0624 substrate plus 2 additional drops of levamisol (K5000 by DakoCytomation) per $3 \mathrm{ml}$ of substrate. The sections were counterstained with hemalaun (DakoCytomation S2020) for 5 min with subsequent blueing for $5 \mathrm{~min}$ in tap water.

All score values given for anti-hTERT, Ki-67 and antinucleolin refer exclusively to nuclear and/or nucleolar stainings in the carcinomas or epithelia and the expression of CD45 in complete tissues. Based on our previous immunohistochemical studies with other antibodies (26-28) we used the immunohistochemical evaluation by Remmele et al $(29,30)$. The evaluation of the sections was performed three times at different time points by an independent examiner and was 
Table II. Overview of primary antibodies used.

\begin{tabular}{lllll}
\hline $\begin{array}{l}\mathrm{Ab} \\
\text { code }\end{array}$ & Antibodies & \multicolumn{1}{c}{ Source, code } & Characterization & $\begin{array}{c}\text { Working } \\
\text { dilution }\end{array}$ \\
\hline $\begin{array}{l}\text { Ab 1 } \\
\text { Polyclonal rabbit } \\
\text { anti-telomerase Ab }\end{array}$ & $\begin{array}{l}\text { Oncogene } \\
\text { (from Calbiochem, USA) } \\
\text { code PC 563 }\end{array}$ & $\begin{array}{l}\text { Anti-hTERT (aa 348-358 of human hTERT). } \\
\text { IgG }\end{array}$ & 1:10 \\
& & &
\end{tabular}

Ab 2 Polyclonal rabbit anti-EST-2 Ab (affinity pure)
Ab 3 Mouse monoclonal anti-telomerase (catalytic unit) liquid $\mathrm{Ab}$ (clone 44F12)

Ab 4 Polyclonal rabbit anti-telomerase $\mathrm{Ab}$
Ab 5 Polyclonal rabbit anti-TERT (H-231) Ab, unconjugated

Ab 6 Polyclonal rabbit anti-telomerase $\mathrm{Ab}$

\section{Ab 7 Polyclonal rabbit} anti-telomerase $\mathrm{Ab}$

Ab 8 Polyclonal rabbit anti-telomerase $\mathrm{Ab}$ (affinity purified)

Ab 9 Polyclonal rabbit anti-telomerase catalytic subunit (hTERT) (affinity purified)

Ab 10 Monoclonal mouse anti-telomerase reverse transcriptase $\mathrm{Ab}$ (clone 2D8)

\author{
Alpha Diagnostics \\ International, USA \\ code EST21-A
}

NovoCastra, UK code NCL-L-hTERT

Calbiochem, USA code 582005

\section{Santa Cruz}

Biotechnology Inc., USA code sc-7212

Calbiochem, USA code 582000
Anti-hTERT against the 16-aa peptide EST21-P, sequence mapping in the middle of human EST-2 was selected for antibody production. The peptide was coupled to KLH, antibody was generated in rabbit. $\mathrm{IgG}_{1}-\mathrm{Ab}$

Against procaryotic recombinant fusion protein $1: 10$ corresponding to a 148 -aa truncate (aa 173-320), a region near the N-terminal. $\mathrm{IgG}_{2 \mathrm{a}}-\kappa-\mathrm{Ab}$

Immunogen used was a synthetic peptide corresponding to an internal region of the catalytic subunit of human telomerase reverse transcriptase (hTERT), recognizes the $\sim 125 \mathrm{kDa}$ telomerase (TERT) protein. $\mathrm{IgG}-\mathrm{Ab}$

Against aa 900-1130 mapping at the

C-terminus of TERT of human origin. $\mathrm{IgG}-\mathrm{Ab}$

Immunogen used was a synthetic peptide corresponding to amino acids from an internal region of the catalytic subunit of human telomerase reverse transcriptase (hTERT), recognizes the $\sim 125 \mathrm{kDa}$ telomerase (TERT) protein. $\mathrm{IgG}-\mathrm{Ab}$

Immunogen a peptide from the mTERT protein component from telomerase. $\mathrm{IgG}-\mathrm{Ab}$

Immunogen a synthetic peptide conjugated

Abcam, USA

to KLH derived from within residues 550-650 of human telomerase.

$\mathrm{IgG}-\mathrm{Ab}$

Rockland, USA

code 600-401-252

The antibody was prepared from whole rabbit serum produced immunization with a synthetic peptide corresponding to a region near the carboxy terminal end of hTERT (aa 1104-1123). IgG-Ab

Novus Biologicals, USA code NB 100-297
Immunogen full-length recombinant hTERT from insect cells.

$\operatorname{IgM}-\mathrm{Ab}$ 
Table II. Continued.

\begin{tabular}{|c|c|c|c|c|}
\hline $\begin{array}{l}\mathrm{Ab} \\
\text { code }\end{array}$ & Antibodies & Source, code & Characterization & $\begin{array}{l}\text { Working } \\
\text { dilution }\end{array}$ \\
\hline $\mathrm{Ab} 11$ & $\begin{array}{l}\text { Monoclonal mouse } \\
\text { anti-telomerase } \\
\text { reverse transcriptase } \\
\text { (clone 2C4) }\end{array}$ & $\begin{array}{l}\text { Novus Biologicals, } \\
\text { USA } \\
\text { code NB 100-317 }\end{array}$ & $\begin{array}{l}\text { Immunogen full-length recombinant hTERT from } \\
\text { insect cells. } \\
\text { IgM-Ab }\end{array}$ & $1: 100$ \\
\hline \multicolumn{5}{|c|}{ Positive control antibodies } \\
\hline $\mathrm{Ab} 12$ & $\begin{array}{l}\text { Monoclonal mouse } \\
\text { anti-human Ki-67 antibody } \\
\text { (clone MIB-1) }\end{array}$ & $\begin{array}{l}\text { Dako, Denmark } \\
\text { code M7240 }\end{array}$ & $\begin{array}{l}\text { Immunogen human recombinant peptide } \\
\text { corresponding to a 1002-bp Ki- } 67 \text { cDNA fragment. } \\
\mathrm{IgG}_{1}-\mathrm{K}-\mathrm{Ab}\end{array}$ & $1: 100$ \\
\hline $\mathrm{Ab} 13$ & $\begin{array}{l}\text { Polyclonal rabbit } \\
\text { antibody against nucleolin }\end{array}$ & $\begin{array}{l}\text { Abcam, USA } \\
\text { code ab22758 }\end{array}$ & $\begin{array}{l}\text { Immunogen synthetic peptide conjugated to KLH } \\
\text { derived within residues } 1-100 \text { from human nucleolin. } \\
\text { IgG }\end{array}$ & $1: 400$ \\
\hline $\mathrm{Ab} 14$ & $\begin{array}{l}\text { Monoclonal mouse } \\
\text { Ab CD45RB } \\
\text { (clone PD7/26), } \\
\text { leucocyte common antigen }\end{array}$ & $\begin{array}{l}\text { Dako, Denmark } \\
\text { code M0833 }\end{array}$ & $\begin{array}{l}\text { Reacts with B cell, T cell subsets, monocytes, } \\
\text { macrophages and weakly with granulocytes. } \\
\mathrm{IgG}_{1}-\mathrm{K}-\mathrm{Ak}\end{array}$ & $1: 100$ \\
\hline
\end{tabular}

aa, amino acid; Ab, antibody; KLH, keyhole limpet hemocyanin.

based on estimated values for staining intensity (SI: 0, no staining; 1+, weak; $2+$, moderate; $3+$, strong and 4+, very strong staining) and percentage of positive staining in tissue sections (PP: 0, no positive cells; 1, 1-25\%; 2, 26-50\%; 3, $51-75 \%$ and $4,76-100 \%$ positive cells). The immunohistochemical score value (IRS) was then calculated by multiplication of SI and PP. The evaluation was performed with a 40-fold objective.

Immunoabsorption to test anti-hTERT antibody specificity. Few commercial peptides were available for these tests: a hTERT peptide EST21-P (Alpha Diagnostics), 16-aa peptide of human EST2. This peptide was used as a homologous immunogen for EST21-A, our Ab 2; a hTERT peptide ab24029 (Abcam, USA), a synthetic peptide derived from within residues 550-650 of human telomerase, and was used as a homologous immunogen for ab23699, our Ab 8; and a nucleolin peptide ab25315 (Abcam), a synthetic peptide derived from within residues 1-100 of human nucleolin, and was used as a homologous immunogen for ab22758 nucleolin$\mathrm{Ab}$, our $\mathrm{Ab} 13$. Using Ki-67 antibodies by DakoCytomation (Ab 12) we tested the suitability of albumin as a control for absorption. We used a 30\% albumin solution (Sigma A-334424, USA) diluted 1:30 in isotonic buffered saline. The immunoreactive score value of Ki-67 expression was the same after absorption in the albumin solution as it was before.

We conducted immunoabsorption following the protocols of Alpha Diagnostics (31) and Abcam (32) with some modification, and the details provided by Frost et al (33). The antibody-peptide mixtures were incubated for $2 \mathrm{~h}$ at $37^{\circ} \mathrm{C}$ and overnight at $4^{\circ} \mathrm{C}$ to facilitate absorption of antibodies binding at higher and/or lower temperatures. For control purposes we substituted peptide with the same quantity of albumin (Sigma A-3424) and used the same volume of antibody dilution (S2022, DakoCytomation). Following incubation we centrifuged the mixtures for $15 \mathrm{~min}$ at $15000 \mathrm{rpm}$ at $4^{\circ} \mathrm{C}$ and applied immunohistochemical techniques on the absorbed portions (including the control portions with albumin) at the usual dilution. Squamous cell carcinomas (30 tissues) and control tissues (13 tissues) with squamous epithelium were examined with the absorbed antibodies. We evaluated the immunoabsorption on the basis of immunoreactive scores of tissues before and after absorption. IRS unchanged after absorption: immunoabsorption of antibody, negative; IRS after slight absorption, 1+; IRS after absorption reduced by half and more, $2+$ to $3+$. Only results of $2+$ and $3+$ were considered adequate for our purpose.

Determining telomerase activity in the same frozen tissue samples. As described above $(13,14)$, we used the test kits TeloTAGGG Telomerase PCR ELISA (Roche Diagnostics, Applied Science, Mannheim, Germany, catalogue no. 11854666910) and TeloTAGGG Telomerase PCR ELISA ${ }^{\text {Plus }}$ (Roche Diagnostics, catalogue no. 12013789001) for demonstration of telomerase activity. The frozen tissues were lysed and the lysate adjusted with the addition of 0.5 and $5 \mu \mathrm{g}$ protein or, if necessary, amounts under $0.5 \mu \mathrm{g}$ per PCR trial. We conducted the examination following suppliers' instructions. It was necessary to use the TeloTAGGG Telomerase PCR ELISA $^{\text {Plus }}$ kit because its internal standards make it possible to check for any false negative findings caused by inhibition 
Table III. Telomerase activity in mOD and expression of hTERT and of control antibodies Ab 12 to Ab 14 (Table II) by IRS in tumor center tissues of oral and extraoral squamous cell carcinomas (patients data see Table I).

\begin{tabular}{|c|c|c|c|c|c|c|c|c|c|c|c|c|c|}
\hline No. & TA-TC ${ }^{\mathrm{a}}$ & $\begin{array}{c}\text { IRS } \\
\text { Ab } 2\end{array}$ & $\begin{array}{c}\text { IRS } \\
\text { Ab } 3\end{array}$ & $\begin{array}{c}\text { IRS } \\
\mathrm{Ab} 4\end{array}$ & $\begin{array}{c}\text { IRS } \\
\text { Ab } 6\end{array}$ & $\begin{array}{c}\text { IRS } \\
\text { Ab } 7\end{array}$ & $\begin{array}{c}\text { IRS } \\
\text { Ab } 8\end{array}$ & $\begin{array}{c}\text { IRS } \\
\text { Ab } 9\end{array}$ & $\begin{array}{c}\text { IRS } \\
\text { Ab } 10\end{array}$ & $\begin{array}{c}\text { IRS } \\
\text { Ab } 11\end{array}$ & $\begin{array}{c}\text { IRS } \\
\text { Ki-67 }\end{array}$ & $\begin{array}{c}\text { IRS } \\
\text { Ab } 13\end{array}$ & $\begin{array}{c}\text { IRS } \\
\text { CD45 }\end{array}$ \\
\hline 1 & 0 & 0 & 12 & 6 & 4 & 12 & 7 & 6 & 12 & 8 & 12 & 10 & 12 \\
\hline 2 & 0 & 2 & 9 & 4 & 1 & 3 & - & 11 & 10 & - & 12 & 12 & 4 \\
\hline 3 & $4+$ & 4 & 0 & 1 & 1 & 11 & 2 & 7 & 11 & 6 & 10 & 11 & 6 \\
\hline 4 & $4+$ & 5 & 12 & 16 & 5 & 12 & 9 & 11 & 10 & 8 & 10 & 10 & 12 \\
\hline 5 & $4+$ & 8 & 12 & 12 & 4 & 16 & 12 & 12 & 6 & 8 & 12 & 12 & 6 \\
\hline 6 & $4+$ & 0 & 8 & 12 & 6 & 10 & 6 & 11 & 9 & 12 & 12 & 12 & 1 \\
\hline 7 & $1+$ & 1 & 9 & 6 & 6 & 6 & - & - & 0 & - & 12 & - & 12 \\
\hline 8 & $4+$ & 0 & 0 & 6 & 2 & 4 & 1 & 6 & 11 & 11 & 8 & 8 & 6 \\
\hline 9 & $1+$ & 8 & 12 & 11 & 3 & 11 & 3 & 9 & 12 & 0 & 14 & 12 & 12 \\
\hline 10 & 0 & 0 & 12 & 7 & 4 & 2 & - & - & - & - & 12 & - & 8 \\
\hline 11 & $4+$ & 1 & 12 & 12 & 9 & 1 & - & - & - & - & 10 & - & 8 \\
\hline 12 & $2+$ & 1 & 8 & 8 & 8 & 3 & - & 2 & - & - & 12 & 5 & 16 \\
\hline 13 & $4+$ & 5 & 9 & 16 & 3 & 11 & 10 & 12 & 9 & 9 & 16 & 14 & 4 \\
\hline 14 & $4+$ & 1 & 12 & 12 & 4 & 9 & - & - & - & - & 12 & - & 4 \\
\hline 15 & $4+$ & 2 & 11 & 6 & 0 & 5 & 1 & 4 & - & 7 & 4 & 12 & 5 \\
\hline 16 & $2+$ & 8 & 12 & 6 & - & 11 & 8 & 3 & 11 & 0 & 12 & 12 & 6 \\
\hline 17 & $4+$ & 0 & 12 & 5 & 3 & 8 & - & - & - & - & 7 & - & 7 \\
\hline 18 & $4+$ & 1 & 1 & 7 & 2 & 7 & - & - & - & - & 6 & - & 3 \\
\hline 19 & $4+$ & 2 & 1 & 7 & 4 & 2 & - & - & - & - & 12 & - & 8 \\
\hline 20 & 0 & 0 & 8 & 4 & 1 & 6 & - & - & - & - & 8 & - & 12 \\
\hline 21 & $4+$ & 3 & 5 & 11 & 6 & 6 & - & - & - & - & 16 & - & 16 \\
\hline 22 & $3+$ & 1 & 12 & 4 & 4 & 9 & - & - & - & - & 12 & - & 12 \\
\hline 23 & $1+$ & 0 & 3 & 5 & 5 & 4 & - & - & - & - & 12 & - & 6 \\
\hline 24 & $2+$ & 0 & 8 & 1 & 1 & 6 & 8 & 10 & 8 & 11 & 10 & 12 & 4 \\
\hline 25 & $4+$ & 0 & 8 & 7 & 0 & 6 & 9 & - & - & - & 8 & 12 & 6 \\
\hline 26 & $2+$ & 9 & 12 & 3 & 1 & 10 & 12 & 11 & 14 & 7 & 16 & 12 & 12 \\
\hline 27 & $3+$ & 5 & 12 & 12 & 9 & 9 & - & - & - & - & 12 & - & 8 \\
\hline 28 & $4+$ & 6 & 8 & 16 & 6 & 11 & 11 & 6 & 6 & 1 & 10 & 12 & 6 \\
\hline 29 & $3+$ & 2 & 12 & 5 & 0 & 5 & - & - & - & - & 12 & - & 6 \\
\hline 30 & $4+$ & 8 & 8 & 8 & 3 & 14 & 14 & 11 & 9 & 9 & 12 & 8 & 16 \\
\hline 31 & $2+$ & 1 & 6 & 4 & 2 & 7 & 2 & - & 8 & 2 & 12 & - & 12 \\
\hline 32 & $2+$ & 1 & 8 & 11 & 3 & 4 & - & - & - & - & 12 & - & 16 \\
\hline 33 & $4+$ & 2 & 5 & 12 & 6 & 7 & - & - & - & - & 8 & - & 8 \\
\hline 34 & $4+$ & 0 & 14 & 6 & 1 & 8 & 10 & 9 & 11 & 9 & 12 & 12 & 12 \\
\hline 35 & $3+$ & 0 & 8 & 11 & 4 & 12 & - & 8 & - & 5 & 8 & 10 & 1 \\
\hline 36 & $4+$ & 5 & 3 & 12 & 4 & 2 & - & - & - & - & 8 & - & 12 \\
\hline 37 & $1+$ & 12 & 8 & 12 & 6 & 11 & 8 & - & 14 & 5 & 12 & 11 & 16 \\
\hline 38 & $4+$ & 0 & 12 & 9 & 5 & 7 & 2 & 12 & 9 & 9 & 12 & 12 & 2 \\
\hline 39 & $3+$ & 4 & 12 & 12 & 2 & 11 & 3 & 6 & 8 & 9 & 10 & 12 & 12 \\
\hline 40 & $2+$ & 2 & 7 & 8 & 2 & 8 & 4 & 5 & 7 & 4 & 16 & 8 & 12 \\
\hline
\end{tabular}

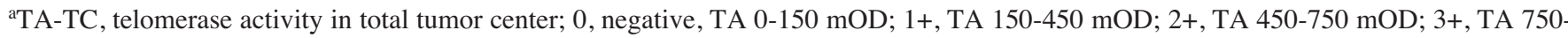
1050 mOD; 4+, TA above 1050 mOD; TC, tumor center; IRS, immunoreactive score; Ab, antibody: Table II; -, not examined.

of the PCR. With a subsequent ELISA it was then possible to detect telomerase activity (TA) in MOD and classify TA into five groups: 0 , negative, TA $0-150 \mathrm{mOD} ; 1+$, TA $150-450$ mOD; 2+, TA 450-750 mOD; 3+, TA 750-1050 mOD; 4+, TA above $1050 \mathrm{mOD}$. The telomerase levels had to be correlated with immunohistochemical hTERT scores.
Statistical evaluation. For statistical evaluation (34), SPSS 15.0 for Windows, version 15.0.1 was available (35). Apart from the descriptive statistics, we compared median values using the Mann-Whitney U test or, if distribution was normal, we compared mean values using the t-test. Given the relatively small number of patients, we reduced all values into two 
Table IV. Telomerase activity in mOD in tumor center tissues, expression of hTERT and Ki-67 by IRS of squamous epithelia (SE) in the oral and extraoral squamous cell carcinoma tissue samples (see Table I).

\begin{tabular}{|c|c|c|c|c|c|c|c|c|c|c|c|}
\hline No. & TA-TC & $\begin{array}{c}\text { IRS } \\
\mathrm{Ab} 2 \\
\mathrm{SE}\end{array}$ & $\begin{array}{c}\text { IRS } \\
\mathrm{Ab} 3 \\
\mathrm{SE}\end{array}$ & $\begin{array}{c}\text { IRS } \\
\mathrm{Ab} 4 \\
\mathrm{SE}\end{array}$ & $\begin{array}{c}\text { IRS } \\
\mathrm{Ab} 6 \\
\mathrm{SE}\end{array}$ & $\begin{array}{c}\text { IRS } \\
\mathrm{Ab} 7 \\
\mathrm{SE}\end{array}$ & $\begin{array}{c}\text { IRS } \\
\mathrm{Ab} 8 \\
\mathrm{SE}\end{array}$ & $\begin{array}{c}\text { IRS } \\
\text { Ab } 9 \\
\text { SE }\end{array}$ & $\begin{array}{c}\text { IRS } \\
\mathrm{Ab} 10 \\
\mathrm{SE}\end{array}$ & $\begin{array}{c}\text { IRS } \\
\text { Ab } 11 \\
\text { SE }\end{array}$ & $\begin{array}{c}\text { IRS } \\
\text { Ki-67 } \\
\text { SE }\end{array}$ \\
\hline 1 & 0 & 4 & 8 & - & 0 & 6 & - & 5 & 9 & 5 & 8 \\
\hline 4 & $4+$ & 5 & 6 & - & 5 & 8 & - & 6 & 8 & 5 & 8 \\
\hline 5 & $4+$ & - & - & 0 & - & - & - & - & - & - & - \\
\hline 6 & $4+$ & 2 & 8 & 8 & 3 & 8 & - & 8 & 7 & 11 & 2 \\
\hline 7 & $1+$ & 1 & 6 & 8 & 4 & 4 & - & - & 1 & - & 12 \\
\hline 9 & $1+$ & 6 & 12 & - & 3 & 7 & 4 & 6 & 9 & 1 & 8 \\
\hline 10 & 0 & 0 & 7 & 12 & 2 & 5 & - & - & - & - & 12 \\
\hline 12 & $2+$ & 0 & 12 & - & 1 & 12 & - & - & - & - & 12 \\
\hline 14 & $4+$ & 1 & 7 & - & 8 & 8 & - & - & - & - & 8 \\
\hline 17 & $4+$ & 0 & 9 & - & 6 & 2 & - & - & - & - & 3 \\
\hline 19 & $4+$ & 5 & 12 & - & 5 & 2 & - & - & - & - & 12 \\
\hline 20 & 0 & - & - & 3 & - & - & - & - & - & - & - \\
\hline 21 & $4+$ & 6 & 11 & 11 & 6 & 6 & - & - & - & - & 8 \\
\hline 22 & $3+$ & 1 & 6 & - & 2 & 6 & - & - & - & - & 6 \\
\hline 23 & $1+$ & 0 & 8 & - & 1 & 2 & - & - & - & - & 16 \\
\hline 24 & $2+$ & - & 8 & 10 & - & - & - & 9 & 9 & 9 & - \\
\hline 25 & $4+$ & 0 & 1 & - & 7 & 8 & - & - & - & - & 8 \\
\hline 26 & $2+$ & 6 & 2 & 0 & 1 & 9 & 10 & 9 & 10 & 5 & 12 \\
\hline 27 & $3+$ & - & - & 14 & - & - & - & - & - & - & - \\
\hline 28 & $4+$ & - & - & 6 & - & - & - & 5 & 7 & 1 & - \\
\hline 29 & $3+$ & - & 12 & 9 & - & 8 & - & - & - & - & 12 \\
\hline 30 & $4+$ & - & 2 & - & - & - & - & 7 & 8 & 5 & 12 \\
\hline 31 & $2+$ & - & - & 7 & - & - & - & - & 8 & 3 & - \\
\hline 32 & $2+$ & 0 & 2 & 3 & 1 & 4 & - & - & - & - & 12 \\
\hline 33 & $4+$ & 6 & 3 & - & 4 & 7 & - & - & - & - & 10 \\
\hline 35 & $3+$ & 0 & 6 & - & 4 & 5 & - & 6 & - & 4 & 12 \\
\hline 36 & $4+$ & 1 & 2 & 6 & 1 & 1 & - & - & - & - & 2 \\
\hline 39 & $3+$ & 0 & 12 & 2 & 0 & 6 & 3 & 4 & 6 & 4 & 8 \\
\hline 40 & $2+$ & 0 & 3 & 5 & 1 & 1 & 5 & 2 & 3 & 3 & 12 \\
\hline
\end{tabular}

aTA-TC, telomerase activity in total tumor center tissue; 0 , negative, TA 0-150 mOD; $1+$, TA 150-450 mOD; 2+, TA 450-750 mOD; 3+, TA 750-1050 mOD; 4+, TA above 1050 mOD; IRS, immunoreactive score; Ab, antibody: Table II; -, no squamous epithelium in section or not examined.

groups for the statistical comparison of incidence (immunoreactive score values and telomerase activity) in the $\chi^{2}$ test or Fisher exact tests. We divided all values into two groups: for group 0 , values $<$ median value and for group 1 , values $\geq$ median value. We chose the median value as the cut-off value because the score values were not normally distributed.

For testing the prognostic statement made by these values in the Kaplan-Meier curves we used the patient outcome documentation in our hospital. We recorded the number of months between tissue excision and relapse. Several patients, particularly patients with extraoral HNSCC, withdrew from the follow-up. We applied to the Kaplan-Meier curves with the hTERT-group 0 (values < median value) and hTERT-group 1 (values $\geq$ median value).

Test results with $\mathrm{p} \leq 0.05$ were rated as statistically significant.

\section{Results}

Since proof of hTERT expression was very weak with both the first antibody (polyclonal anti-telomerase Ab, Oncogene code PC 563) and the fifth antibody (polyclonal anti-TERT Ab H-231, Santa Cruz code sc-7212) (Table II), we used these two antibodies only for a few sections and did not detail the results.

The score values for all tissues without carcinoma cells and without squamous epithelium were very low (tendency towards 0 ) and for this reason were neither listed nor presented in a graph.

Results for tissues from tumor patients: hTERT expression in the tumor center. Tables III and IV summarize the immunoreactive score values for hTERT expression in comparison to telomerase activity as determined by PCR in 


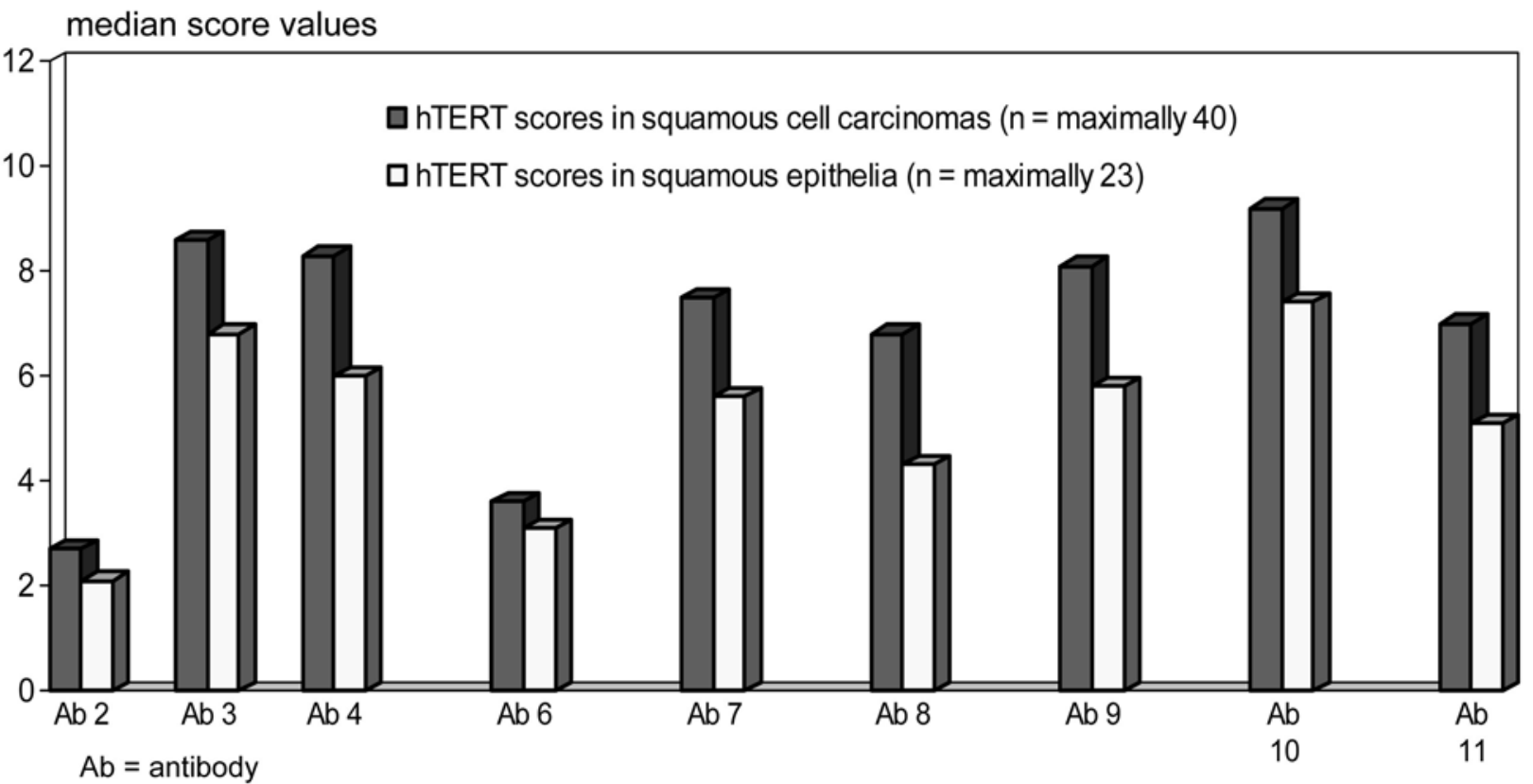

Figure 1. Median values of immunohistochemical score values (IRS) for hTERT expression in the squamous cell carcinomas and squamous epithelium in the same tissue samples. Ab see Table II.

the same tumor center tissue samples. Patient data are given in Table I.

Telomerase activity and hTERT expression yielded with antibodies Ab 3, Ab 6, Ab 8 and Ab 11 as well as with antinucleolin antibody (Ab 13) were higher in oral carcinoma $(n=33$, patients nos. 1-33) than in extraoral carcinoma $(n=7$, patients nos. 34-40). With the other hTERT antibodies (Ab 2, $\mathrm{Ab} 4, \mathrm{Ab} 7, \mathrm{Ab} 9, \mathrm{Ab} 10)$ the values were either the same or higher in extraoral tissue. The $\mathrm{U}$ test (or t-test) rendered no significant difference in IRS between oral and extraoral carcinoma tissue: either in anti-hTERT scores, scores for telomerase activity, scores for Ki-67, anti-nucleolin or CD45. The p-values ranged between 0.136 and 1.000. Localization of the tissue was therefore disregarded in the subsequent results.

The score values of individual antibodies were very heterogeneous, both in squamous cell carcinoma tissue and the squamous epithelium of the same tissue sample, and antibodies for the most part were not distributed normally (Tables III and IV). For this reason the median values for hTERT-expression in Fig. 1 were depicted as graphics.

IRS median values in Fig. 1 reveal that the polyclonal antibodies anti-EST2 (Ab 2) and the anti-telomerase Ab by Calbiochem (code 582000, Ab 6) are least suited for hTERT demonstration in frozen sections and show significantly less hTERT expression in the tissues than do other antibodies. hTERT expression with both these antibodies was however higher than that observed with the two other antibodies not included in Tables III and IV, namely the anti-telomerase Ab code PC 563 by Oncogene (Ab 1) and the Ab 5 (anti-TERT H 231, code sc-7212 by Santa Cruz).

The statistical comparison of immunoreactive score values for the individual antibodies as determined in the MannWhitney U test (or t-test) shows, as does Fig. 1, that the immunohistochemical scores in the squamous carcinomas with the anti-hTERT-antibodies $\mathrm{Ab} \mathrm{3,} \mathrm{Ab} \mathrm{4,} \mathrm{Ab} 6$ and $\mathrm{Ab} 7$ to
Ab 11 are statistically significantly higher than with antibody 2 (code EST21-A) (Tables III and IV). The score values achieved with Ab 6 (Calbiochem code 582000) are statistically significantly lower than those achieved with $\mathrm{Ab} 3, \mathrm{Ab} 4$ and $\mathrm{Ab} 7$ to $\mathrm{Ab} 11$. The score values with Ab 10 (code NB 100-297) are for all tests higher than those yielded by all the other antibodies, and significantly higher than with $\mathrm{Ab} 2(\mathrm{p}<0.01)$, Ab $6(\mathrm{p}<0.01)$, Ab $8(\mathrm{p}=0.035)$ and Ab $11(\mathrm{p}=0.029)$. Score values with $\mathrm{Ab} 3$ (NovoCastra clone 44F12) are only lower than those with the antibodies $\mathrm{Ab} 9$ and $\mathrm{Ab} 10$. In no test was the difference significant.

The score values for hTERT expression with all antihTERT antibodies were higher in carcinoma than in normal or partly dysplastic squamous epithelium present in the same tissue sample (Tables III and IV, Fig. 1). In the U test (or t-test) hTERT expression in carcinoma was, however, not always significantly higher than in squamous cell tissue of the same piece of tissue: $\mathrm{Ab} 2, \mathrm{p}=0.412 ; \mathrm{Ab} 3, \mathrm{p}=0.056 ; \mathrm{Ab} 4$, $\mathrm{p}=0.081 ; \mathrm{Ab} 6,0.463 ; \mathrm{Ab} 7, \mathrm{p}=0.032 ; \mathrm{Ab} \mathrm{8,}=0.528 ; \mathrm{Ab} 9$, $\mathrm{p}=0.024 ; \mathrm{Ab} \mathrm{10}, \mathrm{p}=0.012$ and $\mathrm{Ab} 11, \mathrm{p}=0.043$.

In the $\chi^{2}$ test we explored whether there is a statistical correlation between hTERT expression in the individual antibodies and telomerase activity in squamous cell carcinoma, and formed two groups for this purpose (see statistical evaluation): p-values between 0.086 and 0.876 . It appeared to be the lowest ( $\mathrm{p}=0.086)$ with the monoclonal antibody (clone 2C4) NB 100-317 (Ab 11). This might be because this particular antibody lot had to be filtered and centrifuged to remove foreign particles.

In the same manner we examined expression of $\mathrm{Ki}-67$, nucleolin and CD45 (Table III). No statistical difference was found in the tumor center between the scores with Ki-67 (Ab 12) and with anti-nucleolin (Ab 13): $\mathrm{U}$ test, $\mathrm{p}=0.828$. However, both these scores differed significantly from the proof of lymphocytic infiltration as indicated by the scores 
median score values

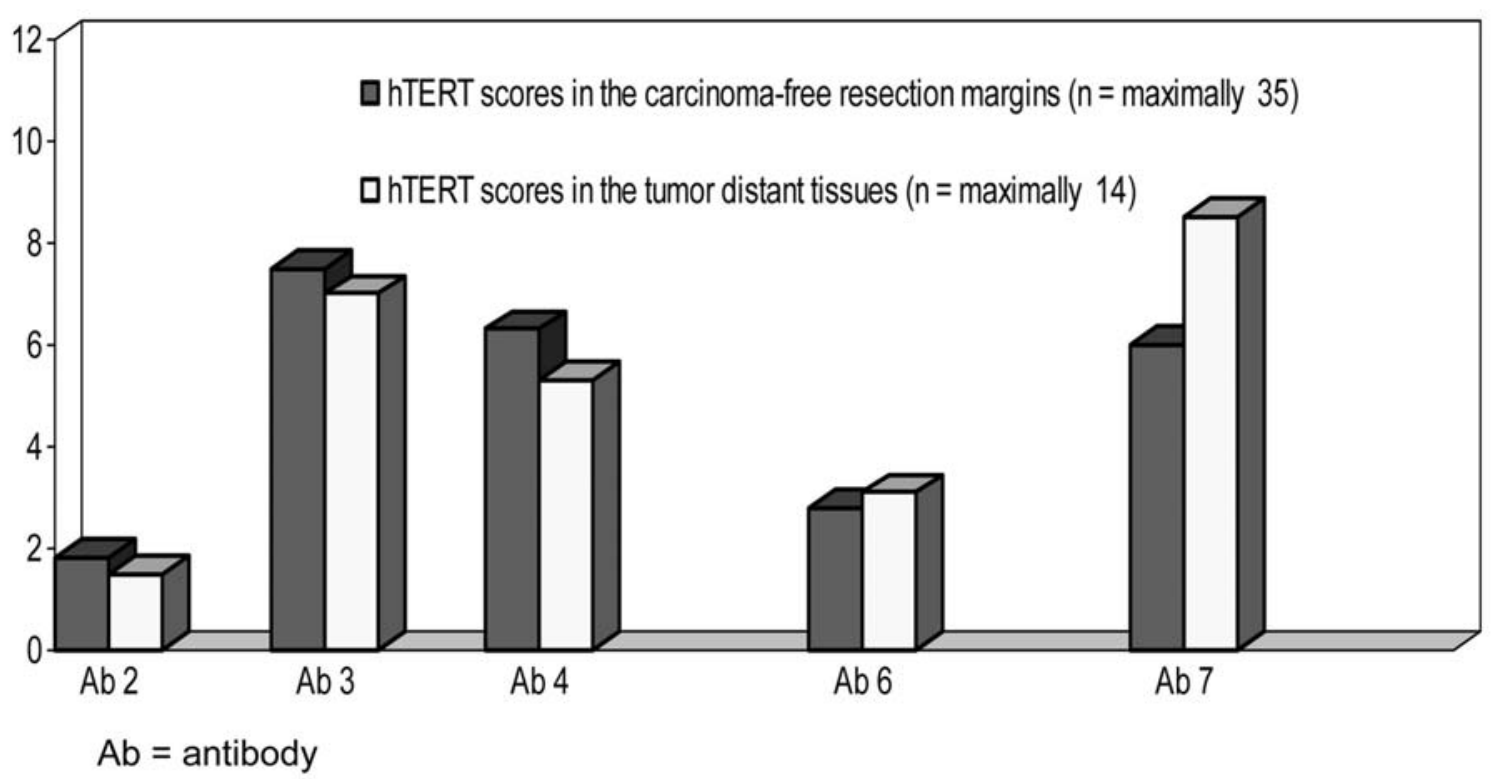

Figure 2. Median values of immunohistochemical score values (IRS) for hTERT expression in squamous epithelium in tumor margins and in tumor distant tissues from the HNSCC. Ab see Table II.

with CD45 (Ab 14) of all tissue types of the tumor centers: $\mathrm{U}$ test, $\mathrm{p}=0.008$ and 0.041 . In the $\chi^{2}$ test (or Fisher exact test) the hTERT expression was compared with the expression of the control antibodies. In the comparison of both Ki-67 and of nucleolin scores with hTERT score values a correlation appears ranging in significance from slight to high. A significant divergence $(\mathrm{p}=0.036)$ appears between nucleolin expression and hTERT scores with the monoclonal anti-hTERT antibody NCL-hTERT (Ab 3). This contradicts observations made by $\mathrm{Wu}$ et al (23). The other p-values are located between 1.000 and 0.191. Between the nucleolin and CD45 expression and telomerase activity there is also a statistical correlation, but not between Ki-67 and telomerase activity $(\mathrm{p}=0.05)$.

Expression of hTERT in tumor-free tumor margin and tumor distant tissue from the patients with squamous cell carcinoma. Table V summarizes the immunoreactive scores for hTERT expression in the squamous epithelium of the carcinoma-free tumor margin and carcinoma-free tumor distant tissue. The scores for Ki-67 in squamous epithelium and evidence of lymphocytic infiltration by CD45 in the tissue samples are also shown. Fig. 2 presents the median values for hTERT expression on squamous epithelium in these tissues.

Evidence for hTERT expression in squamous epithelium is also more moderate as detected by both polyclonal anti-hTERT antibodies, the anti-EST2 (Ab 2) and the anti-telomerase Ab from Calbiochem (code 582000, Ab 6): Fig. 2 (see Fig. 1). A comparison of hTERT score values, as determined with the $\mathrm{U}$ test (or t-test) renders no significant difference between hTERT score values for squamous epithelium in the tumor center, in the tumor margin or in tumor distant tissue, i.e., the values for hTERT expression in these regions are correlated: the hTERT expression in the squamous epithelium adjacent to the carcinoma is statistically no higher than that in the more distant tissue: p-values between 0.114 and 0.972 .
Using the U test (or t-test) we also compared score values for expression of Ki-67 in squamous epithelium and proof of CD45-positive lymphocytic cells in the same tissue areas. Evidence of proliferating epithelial cells (Ki-67 scores) did not differ significantly among the three regions, but lymphocyticmonocytic infiltration was the lowest in the tumor distant region: $\mathrm{p}=0.974(\mathrm{Ki}-67)$ and $\mathrm{p}=0.068(\mathrm{CD} 45)$. There is a correlation between the level of hTERT scores and the intensity of CD45 staining of the lymphocytic infiltration in tumor margin and tumor distant tissue. The correlation was significant only between CD45 and the lowest hTERT scores observed with the antibodies Ab 2 and $\mathrm{Ab} 6(\mathrm{p}<0.001)$.

With the $\chi^{2}$ test we addressed the question of whether there is a correlation between hTERT expression, Ki-67 score values in epithelium, evidence of CD45 in the resection margin and tumor distant tissue, and telomerase activity in the same tissue. No statistical relation was found between telomerase activity in tumor margin tissue and hTERT expression when the polyclonal anti-hTERT antibody EST-2 (Ab 2) was used (tumor margin $\mathrm{p}=0.038$, tumor distant values $\mathrm{p}=0.103$ ), and only a slight correlation was found with the monoclonal antibody code NCL-hTERT (Ab 3): p=0.055 (tumor margin) and $\mathrm{p}=0.103$ (tumor distant tissues). We did find a statistical relationship between hTERT expression with the other hTERTantibodies and telomerase activity in the same tissue (p-values of tumor margin between 0.884 and 0.421 and tumor distant tissues between 1.000 and 0.580 ). The Ki-67 score values (tumor margin $\mathrm{p}=0.052$ and tumor distant tissues $\mathrm{p}=0.580$ ) and the CD45 score values for lymphocytic infiltration (tumor margin $\mathrm{p}=0.751$ and tumor distant tissues $\mathrm{p}=1.000$ ) were also connected to telomerase activity in the same tissue. This correlation was the weakest in squamous epithelium of the tumor margin.

Expression of hTERT in control tissue. Resulting immunoreactive hTERT score values for squamous epithelium are 
Table V. Telomerase activity in mOD, expression of hTERT and of Ki-67 in squamous epithelium from the tumor-free margins (TM) and tumor-free tumor distant tissues (TD) of squamous cell carcinomas as well as of lymphatic infiltration (expression of CD45 in complete sections), see Table I.

\begin{tabular}{|c|c|c|c|c|c|c|c|c|c|c|c|c|c|c|c|c|}
\hline No. & $\begin{array}{l}\mathrm{TA}^{\mathrm{a}}- \\
\mathrm{TM}\end{array}$ & $\begin{array}{c}\text { IRS } \\
\mathrm{Ab} 2\end{array}$ & $\begin{array}{c}\text { IRS } \\
\text { Ab } 3\end{array}$ & $\begin{array}{c}\text { IRS } \\
\mathrm{Ab} 4\end{array}$ & $\begin{array}{c}\text { IRS } \\
\text { Ab } 6\end{array}$ & $\begin{array}{c}\text { IRS } \\
\mathrm{Ab} 7\end{array}$ & $\begin{array}{c}\text { IRS } \\
\text { Ki-67 }\end{array}$ & $\begin{array}{c}\text { IRS } \\
\text { CD45 }\end{array}$ & $\begin{array}{c}\mathrm{TA}^{\mathrm{a}}- \\
\mathrm{TD}\end{array}$ & $\begin{array}{c}\text { IRS } \\
\mathrm{Ab} 2\end{array}$ & $\begin{array}{c}\text { IRS } \\
\text { Ab } 3\end{array}$ & $\begin{array}{c}\text { IRS } \\
\mathrm{Ab} 4\end{array}$ & $\begin{array}{c}\text { IRS } \\
\mathrm{Ab} 6\end{array}$ & $\begin{array}{c}\text { IRS } \\
\mathrm{Ab} 7\end{array}$ & $\begin{array}{c}\text { IRS } \\
\text { Ki-67 }\end{array}$ & $\begin{array}{c}\text { IRS } \\
\text { CD45 }\end{array}$ \\
\hline & SE TM & & & & & & & & SE TD & & & & & & & \\
\hline 2 & - & - & - & - & - & - & - & - & 0 & 1 & 5 & - & - & - & 4 & 1 \\
\hline 5 & $1+$ & 0 & 4 & 0 & 0 & 2 & 1 & 3 & 0 & 2 & 8 & 0 & 0 & 2 & 8 & 8 \\
\hline 6 & 0 & 1 & 8 & 8 & 3 & 4 & 8 & 4 & 0 & - & - & 8 & 3 & 4 & - & 1 \\
\hline 7 & $2+$ & 7 & 6 & 8 & 1 & 6 & 3 & 8 & 0 & - & - & 8 & 1 & 6 & - & 0 \\
\hline 9 & - & - & - & - & - & - & - & - & $1+$ & 0 & 12 & - & - & - & 12 & 5 \\
\hline 10 & $1+$ & 1 & 12 & 12 & 0 & 14 & 6 & 11 & 0 & - & - & 12 & 0 & 14 & - & 2 \\
\hline 12 & - & - & - & - & - & - & - & - & $1+$ & 1 & 6 & - & - & - & 8 & 1 \\
\hline 15 & - & - & - & - & - & - & - & - & $4+$ & 0 & 3 & - & - & - & 12 & 8 \\
\hline 20 & 0 & 1 & 10 & 3 & 3 & 12 & 8 & 4 & - & - & - & - & - & - & - & - \\
\hline 21 & $4+$ & 1 & 8 & 11 & 4 & 6 & 12 & 16 & 0 & - & - & 11 & 4 & 6 & - & 4 \\
\hline 24 & $2+$ & 11 & 3 & 10 & 5 & 10 & 12 & 12 & 0 & 6 & 6 & 10 & 5 & 10 & 12 & 4 \\
\hline 26 & $2+$ & 0 & 0 & 0 & 0 & 12 & 12 & 2 & 0 & 2 & 8 & 0 & 0 & 12 & 4 & 12 \\
\hline 27 & 0 & 0 & 9 & 14 & 0 & 9 & 12 & 12 & - & - & - & - & - & - & - & - \\
\hline 28 & 0 & 6 & 12 & 6 & 4 & 3 & 8 & 7 & - & - & - & - & - & - & - & - \\
\hline 29 & 0 & 9 & 12 & 9 & 2 & 1 & 1 & 6 & $1+$ & 0 & 1 & 9 & 2 & 1 & 8 & 12 \\
\hline 31 & $3+$ & 2 & 5 & 7 & 3 & 6 & 12 & 8 & 0 & 2 & 12 & 7 & 3 & 6 & 8 & 4 \\
\hline 32 & 0 & 5 & 12 & 3 & 7 & 5 & 12 & 16 & - & - & - & - & - & - & - & - \\
\hline 36 & $1+$ & 0 & 5 & 6 & 3 & 5 & 4 & 12 & - & - & - & - & - & - & - & - \\
\hline 38 & 0 & - & - & - & - & - & - & 2 & 0 & 2 & 3 & - & - & - & 12 & 3 \\
\hline 39 & $1+$ & 0 & 6 & 2 & 2 & 3 & 8 & 8 & 0 & 3 & 12 & 2 & 2 & 3 & 2 & 8 \\
\hline 40 & $2+$ & 3 & 8 & 5 & 2 & 0 & 8 & 1 & - & - & - & - & - & - & - & - \\
\hline 41 & 0 & - & 9 & - & - & - & 0 & 0 & - & - & - & - & - & - & - & - \\
\hline 42 & $1+$ & 2 & 8 & 5 & 2 & 5 & 4 & 12 & - & - & - & - & - & - & - & - \\
\hline 43 & 0 & 2 & 1 & 1 & 1 & 1 & 12 & 1 & - & - & - & - & - & - & - & - \\
\hline 44 & $2+$ & 5 & 5 & 11 & 5 & 6 & 8 & 8 & - & - & - & - & - & - & - & - \\
\hline 45 & $1+$ & 1 & 8 & 8 & 2 & 16 & 16 & 12 & - & - & - & - & - & - & - & - \\
\hline 46 & 0 & - & - & - & - & 11 & 4 & 8 & - & - & - & - & - & - & - & - \\
\hline 47 & $1+$ & 8 & 11 & 8 & 8 & 10 & 12 & 12 & - & - & - & - & - & - & - & - \\
\hline 48 & $3+$ & 6 & 7 & 1 & 1 & 5 & 8 & 12 & 0 & 1 & 9 & 1 & 1 & 5 & 12 & 12 \\
\hline 49 & $2+$ & - & - & 6 & - & - & 12 & 0 & - & - & - & - & - & - & - & - \\
\hline 50 & $3+$ & 11 & 4 & 4 & 4 & 5 & 12 & 8 & - & - & - & - & - & - & - & - \\
\hline 51 & $1+$ & 4 & 10 & 3 & - & 3 & 8 & 12 & - & - & - & - & - & - & - & - \\
\hline 52 & 0 & 1 & 2 & 0 & - & - & 8 & 3 & - & - & - & - & - & - & - & - \\
\hline 53 & 0 & 1 & 14 & 5 & 4 & 14 & 12 & 10 & - & - & - & - & - & - & - & - \\
\hline 54 & $2+$ & 5 & 7 & 10 & 10 & 10 & 8 & 4 & - & - & - & - & - & - & - & - \\
\hline 55 & $2+$ & 0 & 1 & 0 & 0 & 0 & 8 & 16 & 0 & - & 10 & 0 & 0 & 0 & 12 & 4 \\
\hline 56 & $1+$ & 12 & 14 & 14 & 5 & 11 & 16 & 14 & - & - & - & - & - & - & - & - \\
\hline 57 & $3+$ & 4 & 6 & 6 & 2 & 6 & 8 & 8 & $1+$ & 0 & 0 & 6 & 2 & 6 & 4 & 0 \\
\hline 58 & $2+$ & 2 & 0 & 8 & 6 & - & 2 & 4 & - & - & - & - & - & - & - & - \\
\hline 59 & $1+$ & 6 & 12 & 12 & 6 & 6 & 8 & 4 & - & - & - & - & - & - & - & - \\
\hline 60 & $1+$ & 0 & 8 & 8 & 4 & 8 & 8 & 12 & - & - & - & - & - & - & - & - \\
\hline 61 & $4+$ & 2 & 14 & 2 & 0 & 14 & 12 & 4 & - & - & - & - & - & - & - & - \\
\hline
\end{tabular}

aTA, telomerase activity; 0, negative, TA 0-150 mOD; 1+, TA 150-450 mOD; 2+, TA 450-750 mOD; 3+, TA 750-1050 mOD; 4+, TA above 1050 mOD; TM, carcinoma-free tumor margin tissue; TD, tumor distant tissue; SE, squamous epithelia; IRS, immunoreactive scores; Ab, antibody: Table II; -, no squamous epithelium in section or was not examined. 
Table VI. Telomerase activity in mOD and expression of hTERT and of Ki-67 in oral and extraoral squamous epithelia of control tissue (IRS).

\begin{tabular}{|c|c|c|c|c|c|c|c|c|c|c|c|c|c|}
\hline $\begin{array}{l}\text { Control } \\
\text { no. }\end{array}$ & $\mathrm{TA}^{\mathrm{a}}$ & $\begin{array}{c}\text { IRS } \\
\mathrm{Ab} 2\end{array}$ & $\begin{array}{c}\text { IRS } \\
\mathrm{Ab} 3\end{array}$ & $\begin{array}{c}\text { IRS } \\
\mathrm{Ab} 4\end{array}$ & $\begin{array}{l}\text { IRS } \\
\mathrm{Ab} 6\end{array}$ & $\begin{array}{c}\text { IRS } \\
\mathrm{Ab} 7\end{array}$ & $\begin{array}{l}\text { IRS } \\
\mathrm{Ab} 8\end{array}$ & $\begin{array}{l}\text { IRS } \\
\mathrm{Ab} 9\end{array}$ & $\begin{array}{c}\text { IRS } \\
\text { Ab } 10\end{array}$ & $\begin{array}{c}\text { IRS } \\
\text { Ab } 11\end{array}$ & $\begin{array}{c}\text { IRS } \\
\text { Ab } 12\end{array}$ & $\begin{array}{c}\text { IRS } \\
\mathrm{Ab} 13\end{array}$ & $\begin{array}{r}\text { IRS } \\
\text { Ab } 1\end{array}$ \\
\hline \multicolumn{14}{|c|}{23 oral tissues } \\
\hline Co 1 & $2+$ & 0 & 4 & 2 & 3 & 3 & - & - & - & - & 1 & - & 1 \\
\hline Co 2 & $2+$ & 8 & 6 & 12 & 12 & 12 & 12 & 6 & - & 0 & 12 & - & 12 \\
\hline Co 3 & 0 & 6 & 14 & 14 & 14 & 12 & 10 & - & - & - & 12 & - & 12 \\
\hline $\mathrm{Co} 4$ & 0 & 8 & 12 & 12 & 2 & 12 & 8 & 10 & 8 & 8 & 10 & 12 & 8 \\
\hline Co 5 & $4+$ & 1 & 16 & 3 & 3 & 9 & - & - & 10 & - & 3 & - & 7 \\
\hline Co 6 & $2+$ & - & 8 & - & - & - & - & - & - & - & 8 & - & 4 \\
\hline Co 7 & 0 & 0 & 8 & 5 & 1 & 3 & - & - & - & - & 12 & - & 12 \\
\hline Co 8 & 0 & 5 & 8 & 5 & - & 12 & 11 & 5 & 10 & 6 & 12 & 12 & 8 \\
\hline Co 9 & 0 & - & 8 & 8 & - & 14 & 6 & 8 & 9 & 8 & 4 & 8 & 2 \\
\hline Co 10 & $2+$ & 2 & 10 & 12 & 4 & 12 & - & - & - & - & 12 & - & 4 \\
\hline Co 11 & $2+$ & 0 & 10 & 8 & 8 & 12 & - & - & - & - & 8 & - & 4 \\
\hline Co 12 & 0 & 10 & 10 & 12 & 0 & 11 & 2 & 4 & - & 4 & 12 & 12 & 8 \\
\hline Co 13 & $1+$ & 0 & 10 & 1 & 1 & 2 & - & - & - & - & 8 & - & 12 \\
\hline Co 14 & $3+$ & 2 & 4 & 8 & 3 & 8 & - & - & - & - & 4 & - & 4 \\
\hline Co 15 & $2+$ & 4 & 12 & 14 & 3 & 12 & - & 5 & - & - & 12 & - & 8 \\
\hline Co 16 & 0 & 0 & - & 10 & 0 & 10 & - & - & - & - & 12 & - & 12 \\
\hline Co 17 & 0 & 0 & 2 & 16 & 6 & 4 & 3 & 12 & 16 & - & 12 & - & 8 \\
\hline Co 18 & 0 & 2 & 2 & 7 & 2 & 4 & 12 & 12 & 0 & 8 & 12 & - & 2 \\
\hline Co 19 & $2+$ & 9 & 5 & 12 & 9 & 10 & 11 & 12 & - & 9 & 12 & - & 8 \\
\hline Co 20 & 0 & 2 & 12 & 12 & 6 & 8 & - & - & 6 & 0 & 12 & - & 8 \\
\hline Co 21 & 0 & 5 & 10 & 7 & 3 & 7 & - & - & - & - & 8 & - & 2 \\
\hline Co 22 & 0 & - & - & - & - & - & 8 & 8 & - & - & 8 & 12 & - \\
\hline Co 23 & $2+$ & 1 & 1 & 12 & 5 & 5 & - & - & - & - & 8 & - & 12 \\
\hline
\end{tabular}

14 extraoral tissues

\begin{tabular}{|c|c|c|c|c|c|c|c|c|c|c|c|c|}
\hline Co 24 & 0 & 2 & 9 & 2 & 2 & 1 & 0 & 4 & 5 & - & 8 & 8 \\
\hline Co 25 & 0 & 1 & 1 & 12 & 5 & 0 & - & - & - & - & 1 & - \\
\hline Co 26 & 0 & 4 & 8 & 12 & 9 & 6 & - & - & - & - & 8 & - \\
\hline Co 27 & 0 & - & 0 & - & - & 0 & - & - & - & - & 8 & - \\
\hline Co 28 & 0 & 0 & 6 & 1 & 1 & 8 & 5 & 10 & 9 & 12 & 8 & 10 \\
\hline Co 29 & 0 & 0 & 6 & 6 & 2 & 0 & - & - & - & - & 8 & - \\
\hline Co 30 & $1+$ & 4 & 0 & 12 & 2 & 0 & - & - & - & - & 4 & - \\
\hline Co 31 & 0 & 2 & 4 & 8 & 0 & 5 & - & - & - & - & 4 & 12 \\
\hline Co 32 & 0 & 0 & 8 & 6 & 0 & 9 & 11 & 12 & 12 & 9 & 4 & 9 \\
\hline Co 33 & 0 & 5 & 12 & 14 & 5 & 12 & 12 & 8 & 12 & 10 & 8 & 14 \\
\hline Co 34 & 0 & 0 & 2 & 10 & 2 & 8 & 0 & 16 & 14 & 11 & 8 & - \\
\hline Co 35 & 0 & 0 & 12 & 8 & 0 & 7 & 4 & 1 & 8 & 0 & 2 & 8 \\
\hline Co 36 & 0 & 1 & 6 & 7 & 15 & 5 & - & - & 2 & - & 8 & - \\
\hline Co 37 & 0 & 0 & 8 & 1 & 0 & 0 & - & - & - & 11 & - & - \\
\hline
\end{tabular}

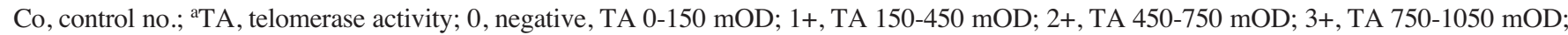
4+, TA above $1050 \mathrm{mOD}$; Ab, antibody: Table II; IRS, immunoreactive scores; -, not examined or no squamous epithelium in section.

listed in Table VI and median values are illustrated in Fig. 3.

Fig. 3 illustrates the low sensitivity of antibodies Ab 2 and Ab 6, disqualifying them for detection of hTERT expression in control tissues. As already distinguishable in Fig. 3 (see
Figs. 1 and 2) the score values for the antibodies Ab 2 and $\mathrm{Ab} 6$ are consistently lower than those for the other antibodies.

The immunoreactive scores of control tissue samples also were very heterogeneously distributed in the squamous epithelium itself and varied with the individual antibody. 


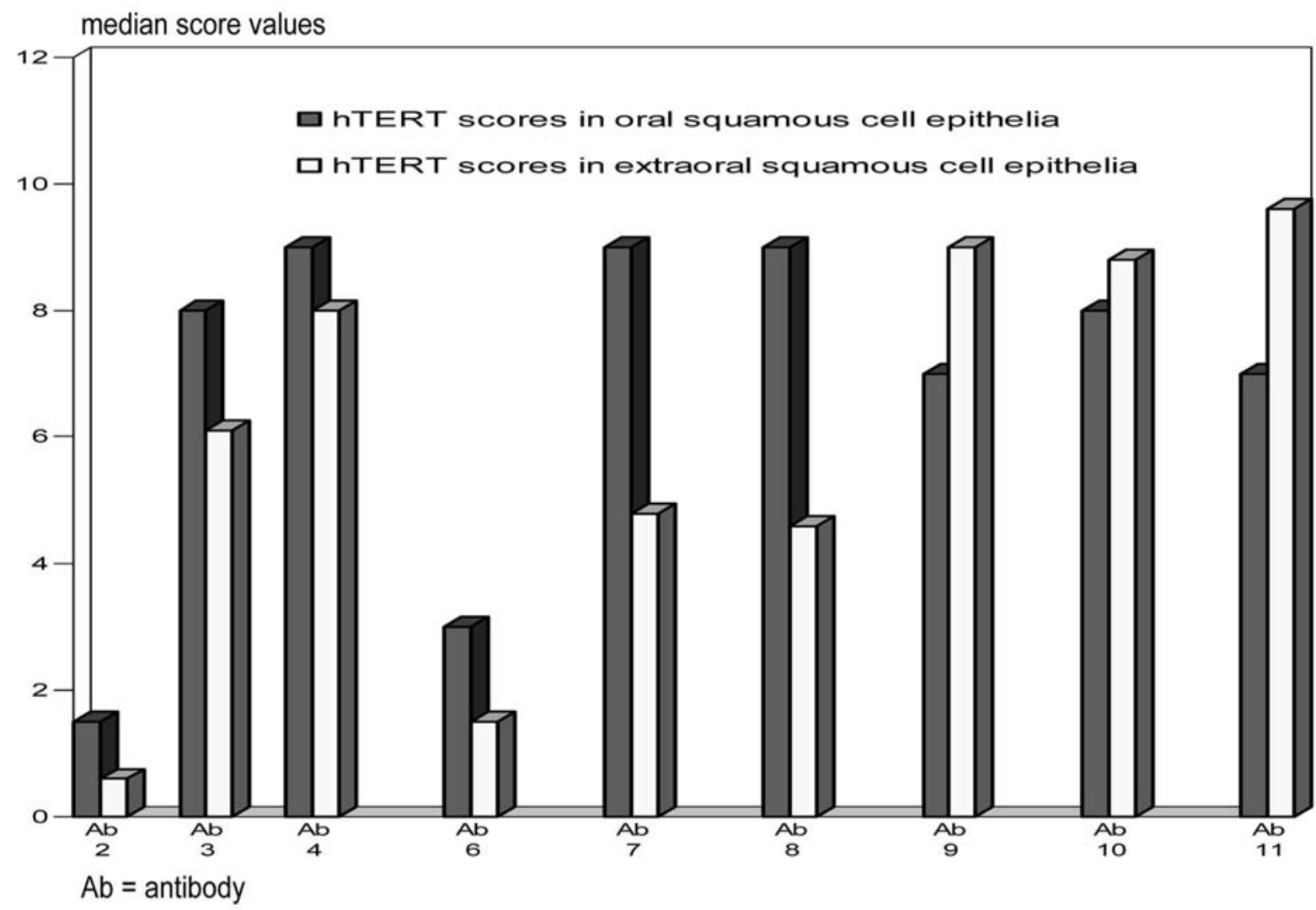

Figure 3. Median values of immunohistochemical score values (IRS) for hTERT expression in control tissues with squamous epithelium. Ab see Table II.

When the immunoreactive score values of oral and extraoral control tissues were compared in the $\mathrm{U}$ test (or the $\mathrm{t}$-test), it was frequently the squamous epithelium of oral tissue which in most tests showed the highest expression. This difference, however, was rarely significant (oral scores were higher with $\mathrm{Ab} 6, \mathrm{p}=0.052$; and significantly higher with $\mathrm{Ab} 7$, $\mathrm{p}=0.010$; extraoral scores were significantly higher with $\mathrm{Ab} 11$, $\mathrm{p}=0.043$ ). With all other antibodies, the difference in expression between oral and extraoral squamous cell carcinoma was insignificant (p-values between 0.103 and 0.886).

Telomerase activity and the expression of Ki-67 (Ab 12), nucleolin (Ab 13) and CD45 (Ab 14) were higher in oral control tissues than in extraoral tissues (Table V). This difference was significant for telomerase activity $(p=0.023)$, $\mathrm{Ki}-67(\mathrm{p}=0.006)$ and CD45 expression $(\mathrm{p}=0.032)$ but was not significant for nucleolin expression $(\mathrm{p}=0.434)$.

The $\chi^{2}$ test between telomerase activity in the control tissues and the hTERT-score values as well as between telomerase activity in the control tissues and the scores for control antibodies showed a connection (all p-values were $>0.05$ ).

Testing the specificity of anti-hTERT antibodies by immunoabsorption. While this study was in progress, Wu et al (23) reported that the monoclonal anti-hTERT antibody NCLhTERT clone 44F12 (Ab 3) primarily identifies nucleolin rather than hTERT. The $\mathrm{Wu}$ group supported this with massspectrometry evidence as well as gel analysis and immunofluorescence. Since immunohistochemical in situ presentation requires an antigen-antibody reaction, we expanded our study to include immunoabsorption of some of our antibodies with two commercially available peptides and one nucleolin peptide. We used the hTERT peptide EST21-P, homologous to the anti-hTERT antibody (Ab 2), the hTERT peptide ab24029, homologous to anti-hTERT antibody $\mathrm{Ab} 8$ and the nucleolin peptide ab25315, homologous to the anti-nucleolin antibody (Ab 13). After immunoabsorption with hTERT peptide EST 21-P and nucleolin peptide, the amount of resulting precipitate was negligible. This was the case both with the homologous antibodies and with the other anti-hTERT antibodies. There was, however, significant precipitate, i.e., precipitating antigenantibody complexes, after immunoabsorption with the hTERT peptide and the homologous antibody $\mathrm{Ab} 8$ and also with the anti-hTERT antibodies Ab 4, Ab 7, Ab 9 and Ab 10. Somewhat less precipitate resulted with $\mathrm{Ab}$ 11. The immunoabsorption of Ab 3 exhibited significant precipitate. In contrast, no precipitate was deposited after immunoabsorption of the antinucleolin antibody, either with the two hTERT peptides or with the homologous nucleolin peptide.

After immunoabsorption and centrifugation of the precipitate, we determined the immunoreactive score values with the absorbed antibodies and compared them before and after absorption. We then determined the percentage of tissues with score values which were markedly lower after absorption than before $(2+$ or $3+$ inhibition of score values by absorption). After incubation with peptide, some of the antibodies showed no or little change in score value (rated as negative immunoabsorption). This might be because the antibody corresponded only partially to the peptide, or, as is more likely, because too little peptide was applied. This was clearly evident with the polyclonal antibodies EST21-A (Ab 2) and ab23699 (Ab 8), 


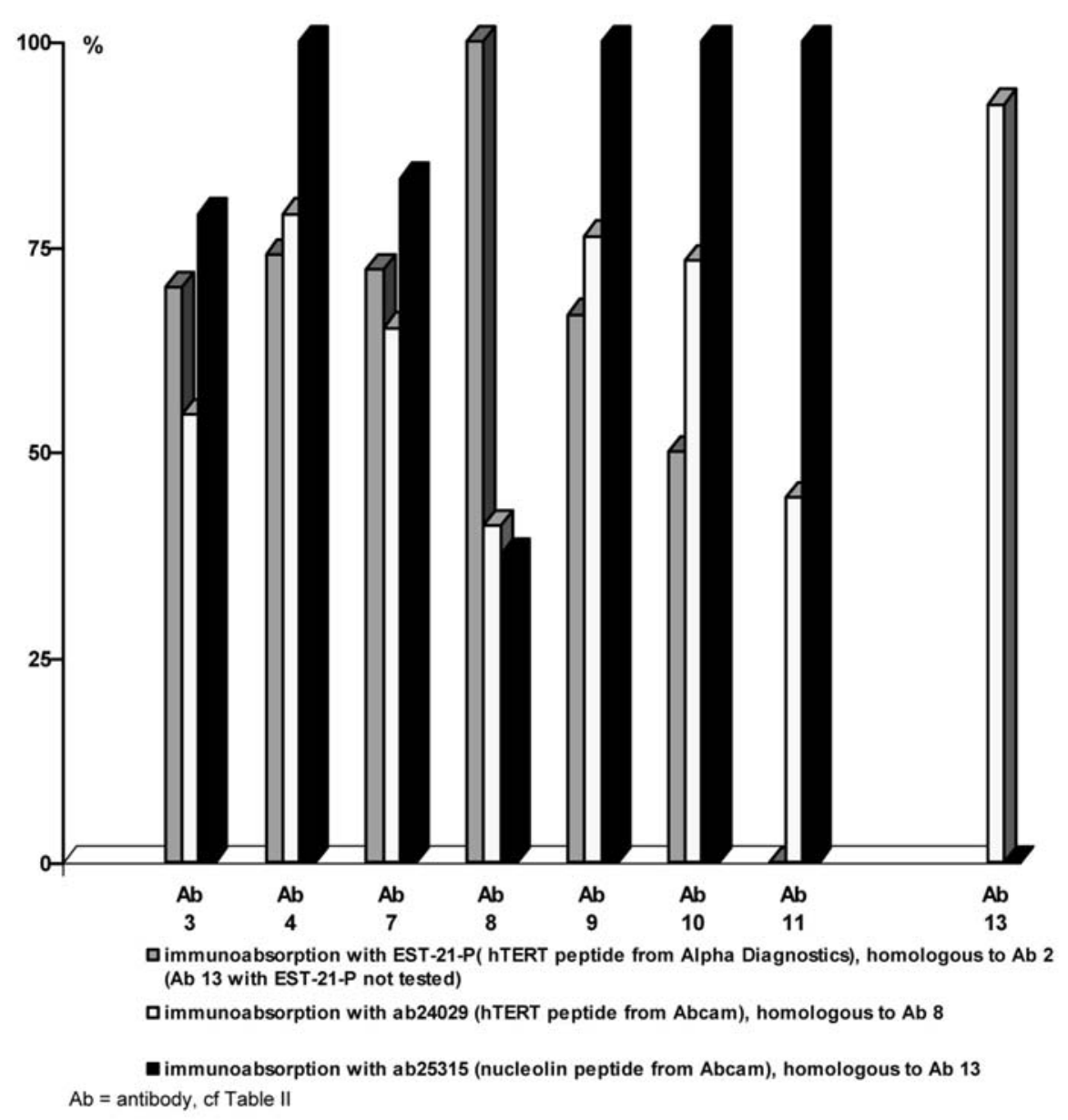

Figure 4. Immunoabsorption of antibodies: $100 \%$, there was no absorption in any tissues; $0 \%$, complete absorption in all tissues.

which even with the homologous peptide used in their production showed only $60 \%$ and $59 \%$ absorption respectively. Adding inert albumin to the antibodies instead of peptide did not reduce their score values. Since the reduced score values resulting in carcinoma tissue and in the squamous cell tissues from the controls were comparable, we summarized absorption results for the anti-hTERT antibodies together in Fig. 4.

Fig. 4 shows the percentage of score values after immunoabsorption. The figure shows that only the anti-hTERT Ab 11 (code NB 100-317) was completely absorbed by the hTERT peptide EST-21-P and only the anti-nucleolin antibody (Ab 13) was completely absorbed by the homologous nucleolin peptide ab25315. The score values for antibodies $\mathrm{Ab} 4$ and $\mathrm{Ab} 9$ to $\mathrm{Ab} 11$ remained unchanged after absorption with the nucleolin peptide ab25315 antibody.

The nucleolin peptide ab25315 absorbed three of the seven anti-hTERT antibodies examined. The monoclonal antibody NCL-hTERT (clone 44F12, Ab 3), characterized by Wu et al as an anti-nucleolin (23), absorbed $21 \%$ of the number of sections examined with the nucleolin peptide $(79 \%$ was not absorbed, Fig. 4). Similar immunoabsorption (17\%) was observed for the polyclonal ab177 (Ab 7, 83\% not absorbed) and a stronger absorption (57\%) by the polyclonal ab23699 (Ab 8, 43\% not absorbed). Conversely, the anti-nucleolin antibody $(\mathrm{Ab} 13)$ is only minimally absorbed ( $8 \%$ of the tissue examined, $92 \%$ not absorbed) by the hTERT peptide ab24029, the immunogen for the polyclonal ab23699, Ab 8 .
Localizing hTERT with selected anti-hTERT antibodies. The distribution of hTERT-positive cells was usually very heterogeneous in the individual squamous cell carcinomas irrespective of the antibody used. Where squamous epithelium in tissues from tumor patients or in control tissue was still normal, the hTERT-positive cells were limited to one or two basal layers. However, in hyperplastic or more or less severely dysplastic squamous epithelium, suprabasal hTERT was also evident, or was spread over the entire squamous epithelium.

Fig. 5 compares the patterns of expression as indicated by the individual anti-hTERT antibodies after pretreatment of the frozen sections in the steamer and visualization in APAAP (25).

Fig. 5 shows some of the immunohistochemical illustrations collected in carcinoma tissues. Application of the polyclonal Ab 2 (not illustrated), polyclonal Ab 4 (Fig. 5b), polyclonal Ab 8 (Fig. 5d), polyclonal Ab 9 (Fig. 5e), monoclonal Ab 10 (Fig. 5f) and monoclonal Ab 11 (not illustrated) induced the typical immunohistochemical pictures of carcinoma and (not illustrated) epithelia staining of the entire nucleus including cytoplasmic staining. With the Ab 4 and $\mathrm{Ab} 11$ we were also able to distinguish non-specific staining in the uppermost keratinous squamous epithelia or background (especially with $\mathrm{Ab} 4)$. Positive staining was also observed with $\mathrm{Ab} 4, \mathrm{Ab} 8$ $\mathrm{Ab} 9$ and $\mathrm{Ab} 11$ in endothelia, lymphocytes/histiocytes or blood cells (not illustrated).

The immunohistological pictures presented by the polyclonal Ab 6 are similar to Ab 4 but clearly weaker, with the 

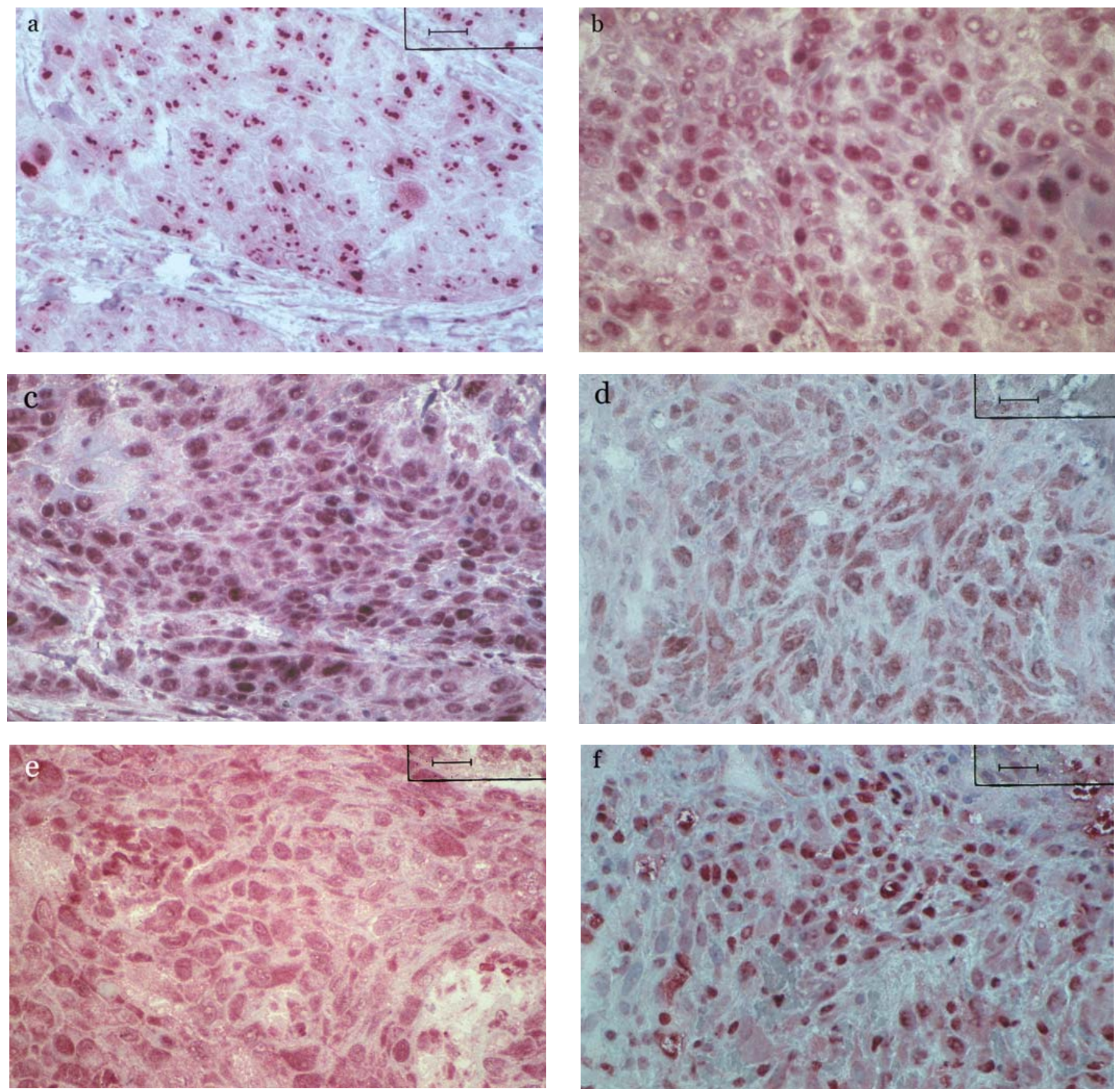

Figure 5. Typical immunohistochemical presentation of hTERT expression (Tables II and III) in oral squamous cell carcinoma (frozen sections) with some antihTERT antibodies: a, Ab 3 (NCL-hTERT); b, Ab 4 (code 592005); c, Ab 7 (code ab177); d, Ab 8 (code ab23699); e, Ab 9 (code 600-401-252) and f, Ab 10 (code NB 100-297); bar, $20 \mu \mathrm{m}$.

background also clearly weaker than with $\mathrm{Ab} 4$. The pictures with the polyclonal Ab 7 (Fig. 5c) and with the monoclonal $\mathrm{Ab} 10$ (Fig. 5f) demonstrated nuclear staining of the entire nucleus, with but little background staining or non-specific staining in the uppermost keratinous squamous epithelia (not illustrated). Ab 10 also stained endothelia, lymphocytes/ histiocytes in connective tissues.

The immunohistochemical pictures of monoclonal $\mathrm{Ab} 3$ (Fig. 5a) were nuclear, with characteristic marking of nucleoli only. Background staining was not observed.

Prognostic significance of immunohistochemical proof of hTERT protein. In order to determine the prognostic significance of hTERT expression we applied Kaplan-Meier curves as described under Patients and methods for each antibody in the carcinoma tissue, in the squamous epithelium in tumor center and tumor margin tissue. The Kaplan-Meier analyses rendered no significant correlation between increased hTERT expression and poor prognosis. The period without recurrence was not significantly shortened in patients with higher hTERT expression (scores $\geq$ the median value). The Kaplan-Meier curves in Fig. 6 show that the increased hTERT expression obtained with the polyclonal Ab 7 (code ab177) correlated with a poor prognosis. The period without recurrence was shortened in patients with hTERT expression $\geq$ IRSmedian. 


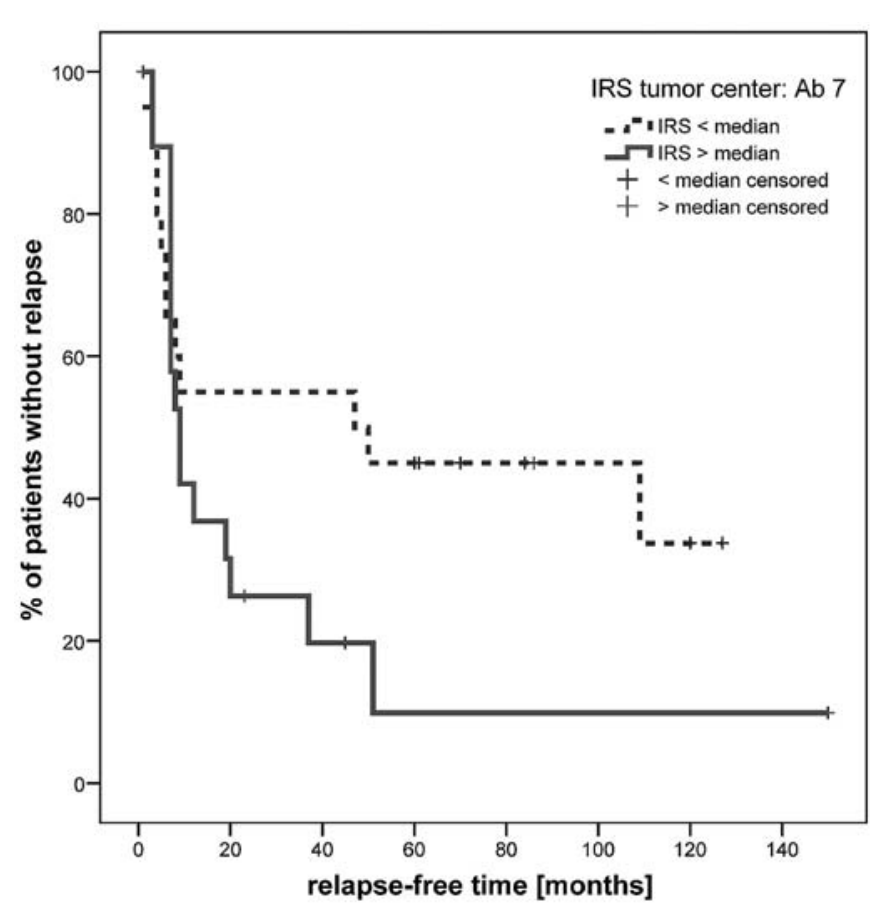

Figure 6. Outcome in 40 patients with a squamous cell carcinoma and hTERT score values with the polyclonal Ab 7 (code ab177) in the tumor center tissues: Kaplan-Meier curve, Log-rank test $\mathrm{p}=0.138$. The mean time period which elapsed until relapse in 20 patients with hTERT score value $\geq$ median value in carcinoma was $29 \pm 11$ months, in 20 patients with score value $<$ median value was $62 \pm 13$ months.

\section{Discussion}

The telomeric repeat amplification protocol (TRAP) developed in 1994 by Kim et al (16) made possible the reproducible demonstration of telomerase in larger studies of various tumors. Since then researchers have been working on hTERT evidence with RT-PCR $(12,18,19,36-40)$ or on proof of telomerase-positive cells by in situ hybridization (12,36-40). This period has also seen the advent of laboratory manufacturing $(33,41-46)$ or commercial (17-22) production of anti-hTERT antibodies for use in immunohistochemistry.

The purpose of the present study was the in situ demonstration of telomerase activation in frozen sections from head and neck tumors and comparison with control tissue from tumor-free patients. In previous studies with these same tissues we had proved telomerase activity in PCR-ELISA (13-15) and determined the corresponding semiquantitative extinction values. Non-carcinomatous tumor margin tissue showed telomerase activation. We wanted to identify the cells responsible for this activity in non-carcinomatous tumor margin and tumor distant tissue and chose as our method the immunohistochemical proof of hTERT, the catalytic subunit of telomerase, in the same frozen tissues in which we had already demonstrated telomerase activity. We were obliged to use commercial antibodies. Some anti-hTERT antibodies gradually became available on the market through the course of our study. At that time, non-commercial (33,41-46) or commercial (17-22) antibodies had only been used for hTERT-proof in paraffin slices or in paraffin-embedded cells.
Immunoreactive hTERT score values in tissue from patients with HNSCC. The relatively heterogeneous tissue examined from patients with an HNSCC (patient data in Table I) was derived from tumors with various staging and grading. The squamous epithelium in these tissue samples also evidenced different histopathological pictures. The small patient number did not allow subdivision of hTERT results into individual groups. We correlated hTERT expression both between the different tissue regions (tumor center, carcinoma-free adjacent tumor margins and tumor distant tissues) and with telomerase activity (Tables III-V). It is clear from hTERT expression in carcinoma (Table III, Figs. 1 and 5), in squamous epithelial tissue of the tumor center tissue (Table IV and Fig. 1), squamous epithelial tissue of the tumor margin (Table $\mathrm{V}$ and Fig. 2) and squamous epithelial cells of tumor distant tissue (Table V and Fig. 2) that the antibodies Ab 4 (code 582005) and Ab 7 (code ab177) can be used for proof of hTERT. Notwithstanding the re-evaluation of anti-hTERT antibodyspecificity by Wu et al (23), Ab 3 (NCL-L-hTERT) can be used also for hTERT-detection. The antibodies Ab 8 to Ab 11, which we used only for tumor center tissue (carcinoma and squamous epithelium), also showed unambiguous immunohistochemical hTERT scores (Fig. 1 and Table III). hTERT scores were higher in the carcinoma than in the squamous epithelial tissue in the same tissue pieces. hTERT expression in the squamous epithelium of tumor margins and tumor distant tissue, however, was higher than or equal to the squamous epithelium in carcinoma tissues.

The patterns of hTERT expression in these frozen sections did not vary essentially from the picture presented on the paraffin sections from HNSCC already examined (47-51). With an antibody not described in more detail, Nguyen et al (47) demonstrated hTERT in all carcinomas examined and, albeit significantly less, in dysplastic squamous epithelia. The authors (47) suppose a correlation between hTERT expression and tumor stage. Kumar et al (48) examined hTERT expression at different stages of oral carcinogenesis using the antibody NCL-hTERT (our Ab 3, Table II) and were able to differentiate between hTERT expression in normal oral mucosa and that in different histological stages of oral carcinogenesis. The authors evaluated only sections in which they had demonstrated more than $50 \%$ hTERT-positive nuclei.

Luzar et al (49) also used hTERT proof with the antibody NCL-hTERT for their study on the carcinogenesis of the larynx carcinoma. They proved an increase in hTERT expression from normal epithelium (average index 0.17) up to that in the carcinoma (average index 0.96). In their extensive study, Chen et al (50) also used the NCL-hTERT antibody and differentiated their results by quantifying the proportions of cytoplasmic and nuclear staining. They examined 21 tissues from oral mucosa, 116 tissues of varying grades of dysplasia and 62 oral SCC tissues and determined hTERT scores comparable with those detected in our study. Immunohistochemical scores are known to be higher on paraffin sections than on frozen sections, a phenomenon which we have already confirmed in earlier investigations $(27,28)$. For their scores, Chen et al (50) multiplied the percentage of positive cells by staining intensity, while, in accordance with Remmele et al $(29,30)$, we reduced the percentage of positive cells between 0 and $100 \%$ to 0 to a maximum of 4 and then 
multiplied this by staining intensity. Our scores lay under the values of Chen et al (50) for the paraffin sections. Using the antibody NCL-hTERT Chen et al determined an average nuclear score of $80 \pm 14$ in normal oral mucosa, $91 \pm 23$ in light dysplasia, $91 \pm 23$ in moderate dysplasia, $93 \pm 21$ in severe dysplasia and $86 \pm 35$ in carcinoma tissues.

In our study, the highest hTERT scores with the same NCL-hTERT antibody were found in carcinoma tissue, with an average value of $8.5 \pm 3.8$, followed by squamous epithelial tissue in the tumor center with $6.8 \pm 3.8$ (Fig. 1), tumor margin tissue with $7.4 \pm 4$ and tumor distant tissue with $6.8 \pm 4$ (Fig. 2). Chen et al (50) also found cytoplasmic scores ranging in ascending order from those found in normal mucosa up to those for carcinoma. We did not make quantitative evaluations of cytoplasmic staining, we observed however that there was no or only little cytoplasmic staining with the NCL-hTERT antibody (Ab 3).

In the study by Freier et al (51) a non-specified polyclonal anti-hTERT antibody by Abcam was used (see our Ab 7 and $\mathrm{Ab} 8$, Table II). The authors compared immunohistochemical results with those attained by fluorescence in situ hybridization and were able to establish cytoplasmic and nuclear hTERT expression (71\%) on 218 squamous cell carcinomas in the oral region which were significantly higher than that on squamous cell carcinomas in larynx samples $(35 / 89 ; 36 \%)$. The authors concluded that higher and more frequent hTERT expression was a suitable target for anti-neoplastic therapy.

Correlation of hTERT score values and telomerase activity in $H N S C C$. None of the few immunohistochemical studies dealing with hTERT on squamous cell carcinomas in the head and neck has correlated its results to telomerase activity (47-51). Gonzalez-Quevedo et al (52), who demonstrated hTERT in the RT-PCR in various tumors, pointed to a direct correlation between telomerase activity (determined in TRAP-ELISA) and hTERT. This was congruent with the findings of Fujimoto et al (53). The authors also demonstrated hTERT in diverse cell cultures, including cell cultures from oral SCC and oral keratinocytes, by RT-PCR and found a good correlation with the telomerase activity determined in TRAP. In carcinoma tissue, the telomerase activity we found by TRAP-ELISA in HNSCC (Tables III and IV) correlated with the hTERT expression we found by immunohistochemistry with all antibodies ( $\chi^{2}$ test: $\left.\mathrm{p}>0.05\right)$. The lowest correlation was found with antibody code NB 100-317 (Ab 11: $\chi^{2}$ test: $\left.\mathrm{p}=0.086\right)$. In surgical tumor margin tissue, the hTERT scores with the antibody EST21-A (Ab 2) and the level of telomerase activity differ significantly: $\chi^{2}$ test: $\mathrm{p}=0.038$. All further hTERT scores in the tumor margin and tumor distant tissues (Table V) correlate in varying degrees with telomerase activity. We ascertained in our study, as had other authors in regard to diverse tumors $(21,52,54-57)$, that the absence of telomerase activity [under $150 \mathrm{mOD}$ (13-15)] does not always coincide with the absence of hTERT expression and vice versa. Shay et al (58) did not always observe a correlation between the levels of telomerase and those of hTERT expression, while Etheridge et al (59) found a strong correlation between telomerase activity and hTERT expression. Only rarely did Wu et al (60) demonstrate hTERT with RT-PCR in telomerasenegative tissues taken from various skin tumors.
With the antibody code 582005 (our Ab 4) hTERT scores did not always correlate with the telomerase activity demonstrated, a result again conforming to Yan et al (21), who moreover also demonstrated hTERT expression in telomerasenegative tissue. This non-correlation was also observed with other antibodies in our study.

Correlation between hTERT score values and clinical outcome of patients with HNSCC. We examined Kaplan-Meier curves for a relationship between our hTERT score values for the individual antibodies and patient outcome. As determined using the antibodies $\mathrm{Ab} 2, \mathrm{Ab} 3, \mathrm{Ab} 7, \mathrm{Ab} 10$ and $\mathrm{Ab} 11$, periods without relapse were shorter, if not significantly shorter, for patients with high hTERT expression in the carcinoma than those for patients with lower hTERT expression. However, we also observed the opposite, i.e., that higher hTERT expression on the squamous epithelium in carcinoma tissue pieces was associated with longer periods of remission ( $\mathrm{Ab} 3$ ). Between the extended Kaplan-Meier curves there were no significant differences. Only the comparison (in the Kaplan-Meier curves) of hTERT expression on carcinoma in the tumor center with the polyclonal anti-hTERT antibody code ab177 (our Ab 7, Table II) approximated any significance. Survival times were distinctly shorter with higher hTERT expression than with lower hTERT expression (Fig. 6).

Pannone et al (61) found no connection between the immunohistochemically determined hTERT and patient outcome with oral HNSCC after surgery therapy. The only exception to this was one high hTERT expression noted in tumor staging I which was associated with poor prognosis. Examining oral HNSCC patients, Chen et al (50) correlated significantly shorter survival times and higher nuclear hTERT expression with the antibody NCl-hTERT (clone 44F12, Ab 3, Table II). Numerous studies on various tumors attest to a connection between hTERT expression (determined in immunohistochemistry or in RT-PCR) and prognosis (18-20, $48,50,54,62-64)$. Nor was the controversial NCL-hTERT antibody $(48,50,63,64)$ the only antibody used in immunohistochemical examinations. A correlation between patient outcome and higher hTERT IRS scores emerged as well with antibody code sc-71212 (H-231, our Ab 5) $(54,62)$ and antibody code 582005 [our Ab $4(20,64)]$. These results are corroborated by very few authors. Toomey et al (65) explored hTERT expression in patients with an operable lung carcinoma using an anti-hTERT antibody by Santa Cruz (code C20) and found no correlation in the Kaplan-Meier curve between high hTERT expression and patient outcome. Tabori et al (66), using our $\mathrm{Ab} 3$ in ependymomas, were able to demonstrate a significantly shorter survival time in patients with higher hTERT expression $(\mathrm{p}=0.05)$. In patients with a mamma carcinoma, hTERT as demonstrated by Elkak et al (67) using the NCL-hTERT antibody (our Ab 3) did not correlate in the $\chi^{2}$ test with lymph node status, grading or tumor size. Mavrommatis et al (68) observed that nuclear hTERT (anti-hTERT code sc- 7215 by Santa Cruz) was a good and independent parameter for the overall survival of patients with a bladder carcinoma.

Immunohistochemical hTERT proof in control tissues. In normal cervix epithelium, Frost et al (33) showed immunohistochemical proof of hTERT in the basal and supra basal 
layers. Depending on the degree of dysplasia, hTERT was also expressed in the higher epithelial layers. With the same monoclonal antibodies (clone 4B1) Wada et al (43) demonstrated basal and somewhat stronger parabasal hTERT in normal vulva mucosa. In paraffin sections, Yan et al (21) used four anti-hTERT antibodies which we had also used (Table II): the polyclonal antibody by Oncogene (PC563; Ab 1) which in our study was very weak; the polyclonal ab177 antibody (in our study $\mathrm{Ab} 7$ ); the polyclonal $\mathrm{Ab} 2$ by Calbiochem (code 582005, in our study Ab 4) and the monoclonal NCI-LhTERT antibody (in our study Ab 3). The authors demonstrated only very little hTERT expression in the basal layer of bladder tissue. Hiyama et al (17), on the other hand, were able to give immunohistochemical evidence in paraffin sections of hTERT expression in a series of normal cells using the antiEST2 antibody (in our study Ab 2): in basal keratinocytes of the skin, in basal cells of the endometrium and in epithelial cells from the mamma, in lymphocytes from tonsils, spleen, thymus, in lymphocytic infiltrates and trophoblasts from placenta. Volpi et al (69) reported nuclear, nucleolar and cytoplasmic proof of hTERT with a monoclonal antibody Tel 366-10 in different cell lines and in normal tissue (skin, prostate, mamma, cervix, bladder, kidney, pancreas and colon). Using the monoclonal NCL-hTERT, Luzar et al (49) found the lowest hTERT expression in normal larynx epithelium from control persons (mean hTERT index 0.17) in comparison to increasing expression in hyperplastic tissue (0.44), in basal hyperplasia (0.54), atypical hyperplasia $(0.91)$, carcinoma in situ (1.05) and in larynx carcinoma (0.96).

In the present study we investigated tissue from patients without tumors. The tissues originated from patients of our clinic with squamous epithelial tissue which was normal only in part, being taken from inflamed tissue or tissue which was hyperplastic or to varying degrees dysplastic. Independent of the polyclonal and monoclonal antibodies used, the hTERT expression was localized in normal squamous tissues in the basal to parabasal layers, in dysplastic squamous epithelium over the entire epithelium. Immunoreactive hTERT scores also varied: Table VI and Fig. 3. In control tissues hTERT scores were also the lowest with antibodies $\mathrm{Ab} 2$ and $\mathrm{Ab}$ 6, as was the case in tissues from HNSCC (Figs. 1 and 2).

Telomerase activity was significantly higher in oral control tissues than in extraoral control tissues $(p=0.023)$, as was the expression of control antibodies Ki-67 $(\mathrm{p}=0.006)$ and CD45 $(\mathrm{p}=0.032)$. hTERT expression was also higher in the oral control tissues with antibodies $\mathrm{Ab} 2$ to $\mathrm{Ab} 8$ than in the extraoral tissues, with Ab 7 significantly higher $(p=0.010)$. In contrast to this, hTERT scores were higher with Ab 9 to Ab 11 in extraoral tissues than in oral tissues, reaching significance with Ab 11 ( $\mathrm{p}=0.043)$. Comparison of the scores of all antibodies shows that the scores diverged significantly between the Ab 3 (NCL-hTERT) and the anti-nucleolin antibody (Ab 13): $\mathrm{p}=0.013$ (U test). There was a correlation between the level of telomerase and the immunoreactive scores $\left(\chi^{2}\right.$ test: $\mathrm{p}>0.05$ ).

As was the case in tumor patient tissues containing no epithelial cells, control patient tissues containing no squamous epithelial cells (not listed in Results) only rarely showed nuclear marking of lymphocytic infiltration in the stroma with the antibodies $\mathrm{Ab} 4, \mathrm{Ab} 6$ or $\mathrm{Ab} 8$ to $\mathrm{Ab} 11$. Endothelia were marked predominantly with hTERT antibodies Ab 4, $\mathrm{Ab} 8, \mathrm{Ab} 9$ to $\mathrm{Ab} 11$.

Nuclear demonstration of hTERT in frozen sections and nuclear demonstration of antibodies showing the best nuclear hTERT staining. Eleven antibodies, Ab 1 to Ab 11 (Table II) were tested in our study for nuclear demonstration of hTERT on frozen sections. Among them was also the controversial NCL-hTERT antibody (23), Ab 3 of our study. We started work with the four antibodies available to us: Ab 1 to $\mathrm{Ab}$ 4. The immunoreactive scores (IRS) achieved in HNSCC with the polyclonal antibody Ab 1 (code PC563) by Oncogene/ Calbiochem were so low that it can be considered unsuitable for frozen sections. As was the case in Yan et al (21), the nuclear staining obtained with our Ab 1 was ambiguous, and we abandoned this antibody.

With the other three antibodies, the two polyclonal antibodies code EST21-A (Ab 2) and code 582005 (Ab 4) and the monoclonal NCL-L-hTERT (clone 44F12, Ab 3), we worked out the best immunohistological localization of hTERT in the nuclei of the frozen sections. These antibodies had already been used successfully by Hiyama et al (17), Poremba et al (18-20), Yan et al (21) and Park et al (22) in paraffinembedded material (tissue, cells). To achieve nuclear staining in frozen sections in our study, methanol-acetone fixation followed by pretreatment in a steamer in a slightly acidic buffer proved the most suitable method. Taylor et al $(70,71)$ had carried out comparisons using immunohistochemical methods as we had between diverse antibodies on paraffin sections without pretreating the sections and after pretreatment in the microwave, autoclave, and steamer. Only with some antibodies did Taylor et al find best results after pretreatment in the steamer. Steamers have been used only rarely for frozen sections (72) and up to now not for anti-hTERT antibodies. We observed occasionally diffuse or a cytoplasmic staining after pretreatment in the steamer. hTERT staining in frozen sections without pretreatment in the steamer was successful predominantly in cytoplasm and only in a few isolated cells with $\mathrm{Ab} 1$ to $\mathrm{Ab} 4$ and the other anti-hTERT antibodies (Table II). For determining the semiquantitative immunoreactive hTERT scores we included only nuclear antibody marking. We agree with Poremba et al (20), who regarded cytoplasmic staining as non-specific and rated it as unlabeled. We recorded cytoplasmic staining as negative, i.e., showing no nuclear marking.

The polyclonal anti-hTERT antibody code EST21-A (Ab 2, Table II) is directed against 16 amino acids of the middle region of the hTERT sequence. It produced the weakest nuclear staining on frozen sections in our preliminary examinations. This was confirmed on an adequate number of tissues (Figs. 1-3 and Tables III-VI). Hiyama et al (17,73-76) achieved strong nuclear hTERT staining with this same antibody on paraffinembedded cells and biopsies, suggesting that EST21-A is less effective for frozen sections. Miyazu et al (75) also demonstrated pronounced hTERT expression on paraffin sections from lung tumors and normal lung squamous tissue. The EST21-A antibody actually produced significant demonstration of hTERT in 23 patients with histopathologically normal epithelium, and patients with higher hTERT expression in epithelial tissue developed lung carcimomas. Similar results 
were recorded by Hashimoto et al (76) in paraffin sections of pancreas tumors and normal pancreas tissue. Higher hTERT expression in pancreatic epithelial tissue points to a malignant transformation.

We achieved particularly good nuclear and even nucleolar marking with the monoclonal antibody NCL-L-hTERT (Ab 3), which is directed against the amino acid sequence 173-320 of the N-terminal domain of the hTERT sequence. This antibody has been applied by many authors in recent years to demonstrate hTERT. Wu et al (23) summarize the most important work done up to 2006 but comment on the use of the NCL-LhTERT for immunohistochemical demonstration of hTERT. From their spectrometric investigation of the antibody, supplemented with findings from two-dimensional gel analysis and immunofluorescence, they concluded that the antibody NCL-hTERT targets nucleolin rather than hTERT.

Having acquainted ourselves with the work by $\mathrm{Wu}$ et al (23), we were particularly careful in evaluating the score values obtained with the controversial antibody. To reinforce our findings we supplemented our study with an additional anti-nucleolin antibody (Ab 13, Table II). As already shown by Ohkoudo et al (77) the immunohistochemical picture after we applied the anti-nucleolin antibody occasionally resembled those with the anti-hTERT antibody NCL-L-hTERT (Ab 3: Fig. 5a).

In their study, Wu et al (23) also included a polyclonal antibody by Calbiochem (code 581400) directed against the amino acid sequences 568-581, the central domain of the hTERT peptide sequence. We suspect that this antibody is comparable to the two polyclonal antibodies by Calbiochem, $\mathrm{Ab} 4$ (code 582005) and Ab 6 (code 582000) used in our study. $\mathrm{Ab} 4$ and $\mathrm{Ab} 6$ are directed against an unknown immunogen in the internal region of the hTERT sequence. In our preliminary investigations the antibody code 582005 (Ab 4, Fig. 5b) displayed clear staining of the entire nucleus with simultaneous cytoplasmic staining and non-specific background staining. Our results with the frozen sections were comparable to those published for paraffin sections $(18-22,64,78,79)$. Like Yan et al (21), we found that this pronounced cytoplasmic staining made evaluation of immunoreactive scores difficult. By contrast, the distinct nucleolar picture presented by the antibody NCL-LhTERT (Ab 3, Fig. 5a) made semiquantitative detection of score values easier.

The values rendered with the polyclonal TERT (H-231) antibody, code sc-7212 (Ab 5) ranged from very low to negative. This antibody is recommended by the manufacturer for immunofluorescence and has been reported by Wei and Younes (62), Hoang-Vu et al (54) and Boltze et al (80) to give good proof of hTERT in a variety of different tumors. However, given the results we obtained, we abandoned its further use and did not report in detail the results obtained with it.

With the polyclonal antibody code 582000 (Ab 6, Table V) background staining was markedly weaker than with antibody code 582005 (Ab 4). Just as with hTERT scores with Ab 2 (code EST21-A), however, values with Ab 6 were much lower than those with other antibodies, particularly with the antibody Calbiochem code 582005 (Ab 4) (Figs. 1-3).

We investigated two polyclonal anti-hTERT antibodies by Abcam (our Ab 7 = code ab177 and its successor, code ab23699, our Ab 8, Table II). Both showed nuclear staining (Ab 7: Fig. 5c and Ab 8: Fig. 5d). hTERT score values were higher with the antibody code ab177 (Figs. 1-3). With the same antibody, Yan et al (21) had obtained only cytoplasmic staining in paraffin slides of telomerase-positive and telomerasenegative tissues.

To validate the results of their immunohistochemical study on giant cell tumors, Forsyth et al (81) applied the monoclonal antibody NCL-hTERT as well as the same polyclonal antihTERT antibody code 600-401-252 (Rockland) used by Wu et al (23) (in our study Ab 9, Table II). The two antibodies yielded similar nuclear staining of osteoclasts and mononuclear cells, with one or more than one small-to-large aggregates in the nucleus. Applying the same antibody, we observed nuclear staining of carcinomas, squamous epithelial cells, endothelial cells and occasional blood cells. Forsyth et al (81) also observed, along with a staining of nuclear aggregates, a diffuse distribution of nuclear staining and fine granular cytoplasmic staining. Neither Forsyth et al (81) nor we observed any cytoplasmic staining with the antibody NCL-hTERT (our $\mathrm{Ab} 3)$. Wu et al (23, and supplementary Fig. 1 therein) consider the polyclonal antibody by Rockland, which is directed against the C-terminal domain of the hTERT sequence (aa 1104-1123), to be the most important of the anti-hTERT antibodies studied by them. Our immunohistological images with the code 600-401-252 antibody by Rockland (Figs. 1-3 and $5 \mathrm{e}$ ) displayed clear nuclear marking and cytoplasmic staining. It is noteworthy that the hTERT scores were higher in the squamous epithelial cells of extraoral control tissue than in the oral tissues (Fig. 3).

We obtained clear nuclear marking with both of the monoclonal anti-hTERT antibodies by Novus Biologicals (Table II) $\mathrm{Ab} 10$ and Ab 11 (clone 2D8, code NB 100-297 and clone $2 \mathrm{C} 4$, code NB 100-317). In most cases the entire nucleus was marked (see Ab 10: Fig. 5f). In our investigation with Ab 11 (code NB 100-317) the cytoplasm was also partially marked. Both are IgM antibodies, as opposed to all other anti-hTERT antibodies used by us, which belong to the IgG classification. The two antibodies are directed against the entire length of the hTERT peptide sequence (aa 1-1132). The code NB100-317 antibody was also studied by $\mathrm{Wu}$ et al (23). Using immunofluorescence, Masutomi et al (82) detected a subcellular localization of hTERT on mortal and immortal human cell lines with the monoclonal anti-hTERT antibody clone $2 \mathrm{C} 4$ (Ab 11, Table II). The nuclear pattern with this antibody was comparable to a polyclonal (not specified) anti-hTERT antibody. In addition, the authors found nucleoplasmatic staining with this antibody, corroborating our results. Lin et al (83), using the monoclonal anti-hTERT antibody clone $2 \mathrm{C} 4$ by Abcam in mutational exclusion studies, were able to confirm a diffuse nuclear localization with the antibody.

Using the three control antibodies Ab 12 to Ab 14 (Table II) we also applied the steamer for the immunohistochemical demonstration of Ki-67, nucleolin and CD45 expression. However, pretreatment of the frozen sections was not crucial for these antibodies. Originally we used the monoclonal antibody PCNA (proliferating cell nuclear antigen, clone PC 10, code M0879, Dako) as a marker for proliferation instead of Ki-67, but it labeled only cells in the S-phase, in which telomerase and hTERT expression are at their maximum (84). The PCNA 
score values yielded by our immunohistochemical processing were however very low, so we used Ki-67 (Ab 12) throughout the entire study in spite of the fact that with this antibody all cells in the cell cycle are marked. Ki-67 (score values in Tables III-VI) had the further advantage that it allowed easy recognition of any small carcinomatous areas on the frozen sections.

Specificity of anti-hTERT antibodies applied. In our study the antibody Ab 3 (NCL-L-hTERT, Table II) characteristically showed predominantly nucleolar staining (Fig. 5a). We extended the scope of our study with immunoabsorption tests to determine whether $\mathrm{Ab} 3$ and other anti-hTERT antibodies indicate nucleolin. Most antibodies in our study were absorbed with one nucleolin peptide and two hTERT peptides. Thus, we included an anti-nucleolin antibody (Ab 13, Table II). As a peptide control we used albumin, as had Frost et al (33). Neither in the experiments of Frost et al nor in ours did the albumin inhibit any of the antibodies. Frost et al (33) used their own monoclonal antibody [clone 4B1 (46)] against hTERT sequence aa 549-831 for the immunoabsorption and were able to completely block the diluted antibody with $375 \mathrm{ng}$ hTERT protein. In the immunoabsorption of a polyclonal anti-prostaglandin receptor antibody to determine antibody specificity, Nakamura et al (85) used 16 times more peptide than antibody and achieved the same effect as had Frost et al (33). Blocking tests have also been used to determine antibody specificity. Klinck et al (86) investigated 4 monoclonal antibodies on pancreas sections using immunofluorescent techniques before and after peptide blocking and were thus able to characterize the antibodies.

To demonstrate successful absorption, we, like Frost et al (33), subjected the antibodies to immunohistochemical investigation with and without absorption. We increased the number of sections included to minimize subjectivity in score evaluation. This in turn required substantial volumes of antibody, and the amounts of peptide we used achieved in fact only partial antibody absorption (Fig. 4). The fact that antibody Ab 8 was only partially blocked by their homologous peptides ab23699 indicates that the amounts of peptide used were insufficient. It is also conceivable that peptides and antibodies were only partially homologous.

Absorption of the antibodies by the peptide EST-21-P (homologous to $\mathrm{Ab} 2$ in our study) was low: Ab 10 (50\%), Ab 9 (33\%), Ab 3 (30\%), Ab 7 (28\%), Ab 4 (26\%) and Ab 8 (no absorption) (Fig. 4). Ab 11 (NB 100-317) absorption with EST21-P was not tested.

The polyclonal antibody ab23699 (Ab 8) was 59\% absorbed (score after absorption $41 \%$ ) by the homologous peptide ab24029. The percentages for other antibodies absorbed by this peptide were lower: $\mathrm{Ab} 11$ (56\%), Ab 3 (46\%), Ab 7 (35\%), $\mathrm{Ab} 10$ (27\%), Ab 9 (24\%) and Ab 4 (21\%). Only 8\% of the anti-nucleolin antibody (Ab 13, Table II) was absorbed by the hTERT peptide ab24029 (score after absorption 92\%).

The homologous nucleolin peptide ab25315 absorbed 100\% of the anti-nucleolin antibody (Ab 13, Table II) but did not in any test block the antibodies $\mathrm{Ab} 4, \mathrm{Ab} 9, \mathrm{Ab} 10$ or $\mathrm{Ab} 11$. The other antibodies were absorbed by the nucleolin peptide as follows: Ab 8 (60\%), Ab 3 (21\%), Ab 7 (17\%). Only $21 \%$ of the anti-hTERT antibody NCL-L-hTERT, which according to $\mathrm{Wu}$ et al (23) is an anti-nucleolin antibody, was absorbed by the nucleolin peptide, but $30 \%$ and $46 \%$ of the same antibody was also absorbed respectively by the two hTERT peptides EST21-P and ab24029. Although our immunoabsorption results are not unambiguous, they nevertheless support the view that not only nucleolin is demonstrated by the antibody NCL-L-hTERT. We may conclude that the antibody $\mathrm{Ab} 3$ is not exclusively directed against nucleolin, but that the antibodies $\mathrm{Ab}$ 4, $\mathrm{Ab} 9, \mathrm{Ab} 10$ and $\mathrm{Ab} 11$ are not directed against nucleolin (Fig. 4). While the polyclonal antibody $\mathrm{Ab} 4$ is directed against the (unspecified) internal hTERT region and the polyclonal Ab 9 against the $\mathrm{C}$ terminal domain (aa 1104-1123), the monoclonal antibodies Ab 10 and $\mathrm{Ab} 11$ are directed against the entire length of the hTERT peptide sequence.

Proof of hTERT and telomerase function. With anti-hTERT antibodies 2-4 and 6-11 we were able to demonstrate nuclear hTERT expression of varying intensity (Figs. 1-3 and 5), albeit directed at different hTERT domains. Whether this test is related to a function of telomerase can not be determined on the basis of the immunohistochemical scores. From the studies by Etheridge et al (59) and Wong et al (87) it is known that temporary hTERT expression is concentrated in the nucleoplasm of human cells, particularly in the nucleolus. Zhu et al (88) confirmed this location to Cajal bodies with fluorescent in situ hybridization in HeLa cells and in some other carcinoma cell lines. Yang et al (89) found through fluorescence tagging experiments that the nucleolar localization of hTERT depends on the N-terminus (aa 1-15) of hTERT (23) and is associated with telomerase function. This localization is cell cycle dependent. Lin et al (83) were able to show by hTERT mutation of residues 254 and 265 in HeLa cells that the nucleolar binding of hTERT and telomerase function are not identical and that mutational inactivation of hTERT C-terminals 965-981 maintains telomerase function despite suspension of nucleolar binding in human and mouse cell lines (90).

The third antibody used in this study (NCL hTERT, Table II), with its typical nucleolar marking (Fig. 5a), is directed against an $\mathrm{N}$ terminal hTERT sequence. Lam et al (63) verified with the NCL-L-hTERT antibody that telomerase and nucleolin interact with one another and display the same intracellular distribution. They concluded that despite the criticism of Wu et al (23) telomerase activity can also be demonstrated with this antibody. Nucleolin is a nucleolar phosphoprotein (91) used with nucleolin-specific antibodies to identify nucleoli (92). Khurts et al (91) revealed that nucleolin interacts with telomerase and changes its subcellular localization. In this process it can bind with hTERT, with significant consequences for its nucleolar localization.

Cells which may be responsible for telomerase activity outside the carcinoma (tumor margin tissue, tumor distant tissue, and control tissue). Mao et al $(10,93)$ demonstrated telomerase in carcinoma-free tumor margins in head and neck tumors and addressed the question of whether the presence of telomerase activation occurs by lymphocytic infiltration in the tissue or whether it was an expression of field cancerization $(1,2)$ in the region surrounding the tumor. In previous examinations we 
had demonstrated a limited correlation between telomerase activity and lymphocyte infiltration in tumor margin tissues $(13,14,94,95)$.

Hiyama et al (94), Counter et al (96) and Broccoli et al (97) demonstrated a low level of telomerase activity in hematogenic cells which was higher in stimulated lymphocytes $(94,97,98)$. Shay and Wright $(99)$ observed telomerase activity of the mononuclear cells in 124 blood samples the intensity of which varied with the number of cells used.

Detectable lymphocytic infiltration has been described in HNSCC tumor margin tissue (100-103). We applied a monoclonal CD45 antibody (Ab 14, Table II) to evaluate lymphocytic-monocytic infiltrates. Statistical comparison revealed a significant variance between the CD45 scores and the extremely low hTERT score values with antibodies Ab 2 and $\mathrm{Ab} 6$ in the tumor margin of squamous cell carcinoma and with antibody $\mathrm{Ab} 2$ in tumor distant tissue of SCC patients. In the tumor margin tissue there was no significant difference between hTERT scores revealed by clearly marked antibodies (Ab 3, Ab 4 and Ab 7) and the CD45 scores. The CD45 scores were significantly higher in oral control tissues than in extraoral control tissues $(\mathrm{p}=0.032)$ (Table VI). In earlier studies we rarely observed a correlation between telomerase levels in the tumor margin and tumor distant tissues of HNSCC and the lymphocytic infiltrates detected by histopathology $(13,14)$. We demonstrated only isolated hTERT marked cells in the stroma of these tissues.

To check for field cancerization $(1,2)$ in tumor margin tissue which had been histopathologically characterized as carcinoma-free, we investigated the hTERT scores of squamous epithelial cells in the tissues (Fig. 2 and Table V) with the antibodies $\mathrm{Ab} 2$ to $\mathrm{Ab} 4, \mathrm{Ab} 6$ and $\mathrm{Ab} 7 . \mathrm{Kim}$ et al had identified telomerase activity in $38 \%$ (16), Mao et al in $43 \%$ (10), Hohaus et al in 76\% (104), Patel et al in 74\% (11) and Yajima et al in 19.4\% (93) of carcinoma-free tumor margin tissues some of which were dysplastic. In the present study we found positive telomerase values (13-15) in 52\% of the tumor margin and $30 \%$ of the tumor distant tissues of patients with squamous cell carcinomas.

Up to now only few tumor margin tissues from head and neck tumors have been inspected for hTERT. Luzar et al (49) compared immunohistochemical proof of hTERT detected with the NCL- hTERT antibody (our Ab 3) with RT-PCR results in tumor margin tissues from larynx carcinomas showing varying degrees of hyperplasia. Both methods showed that increasing hTERT expression is an early event in larynx carcinogenesis. This concurs with the results of Eissa et al (105), who with real-time PCR and fluorescence cytophotometry found lower hTERT levels in larynx tumor margin tissue than in the carcinomas.

The present investigations showed that in addition to the lymphocytic infiltrates in carcinoma-free tumor margin tissues, hTERT was also expressed in squamous epithelial cells distributed in the basal but also in the suprabasal layer and throughout the entire squamous epithelium of the same tissues. hTERT expression was highest when the antibodies Ab 3, Ab 4 and Ab 7 (Table II) were applied (Fig. 2, Table IV). $\chi^{2}$ test registered a correlation between hTERT scores and telomerase activation. The result emerging from these investigations was that lymphocytic infiltration and especially field cancerization of the squamous epithelium in carcinoma-free resection margins are the cause of telomerase activity in these tissues. Whether hTERT is a suitable target for adjuvant therapy of head and neck tumors, as is suggested by Freier et al (51), cannot be determined in our experiments unambiguously.

For our study of hTERT-detection in the squamous epithelia of carcinoma free tumor margins and tumor distant tissues (Fig. 2) we applied antibodies Ab 2, Ab 3, Ab 4, Ab 6 and $\mathrm{Ab} 7$. Ab 3 (code NCL-hTERT), Ab 4 (code 582005) and Ab 7 (code ab177) were particularly suited for causing sensitive hTERT reaction in field cancerization of these tissues or for demonstrating disseminated individual carcinoma cells (minimal residual disease/MRD). Ab 8 to $\mathrm{Ab} 11$ were not applied to tumor margin and tumor distant tissues, but in immunohistochemical testing exhibited intense nuclear and/ or nucleolar marking in carcinoma (Table III, Fig. 1) and in the squamous epithelium of the HNSCC tumor center (Table IV, Fig. 1). That is why Ab 8 (code ab23699), Ab 9 (code 600401-252), Ab 10 (code NB 100-297) and Ab 11 (code NB 100-317) are also well suited for the detection of hTERT expression and field cancerization. Considering the evidence given by $\mathrm{Wu}$ et al $(23,106)$ and our results for immunoabsorption, the following conclusion can be drawn: antibodies $\mathrm{Ab} 4$ and $\mathrm{Ab} 9$ to $\mathrm{Ab} 11$ are particularly well suited for identifying field cancerization and for proof of MRD. We were unable to demonstrate absorption of these antibodies with the nucleolin peptide ab25315 (Fig. 4). If necessary Ab 3 is also useful for demonstrating both field cancerization and MRD. In the Fisher exact test a correlation appears between the level of hTERT scores for these 5 antibodies and telomerase activity (Table III): p-values between 0.086 (Ab 11) and 0.752 (Ab 3).

We agree with Lantuejoul et al (107), however, that it is important to develop new anti-hTERT antibodies against proteins or peptides which do not react or cross-react with nucleolin. Manufacturers of the NCL-L-hTERT antibody should feel prompted by the critical publications of $\mathrm{Wu}$ et al to re-examine the antigen specificity of their antibody. Xiao et al (106) conclude from their studies on culture cells and tissues fixated in formalin that chicken IgG antibodies can have definite advantages over the commonly used mammal IgG antibodies and exhibit less non-specific staining. Irrespective of the afore-mentioned objections, many authors continue to use the monoclonal NCL-L-hTERT for immunohistochemical proof of hTERT $(63,66,107-112)$.

\section{Acknowledgements}

We thank Mrs. Catherine Aubel for language editing. The study was supported by grants from the Berlin Sparkasse Foundation for Medicine.

\section{References}

1. Slaughter D, Southwick H and Smejkal W: Field cancerization in oral stratified squamous epithelium. Cancer 6: 963-968, 1953.

2. Braakhuis BJ, Tabor MP, Kummer JA, Leemans CR and Brakenhoff RH: A genetic explanation of Slaughter's concept of field cancerization: evidence and clinical implications. Cancer Res 63: 1727-1730, 2003. 
3. Brennan JA, Mao L, Hruban RH, Boyle JO, Eby YJ, Koch WM, Goodman SN and Sidransky D: Molecular assessment of histopathological staging in squamous-cell carcinoma of the head and neck. N Engl J Med 332: 429-435, 1995.

4. Bryne M: Is the invasive front of an oral carcinoma the most important area for prognostication? Oral Dis 4: 70-77, 1998.

5. Van Houten VM, Tabor MP, van den Brekel MW, Denkers F, Wishaupt RG, Kummer JA, Snow GB and Brakenhoff RH: Molecular assays for the diagnosis of minimal residual headand-neck cancer: methods, reliability, pitfalls, and solutions. Clin Cancer Res 6: 3803-3816, 2000.

6. Van Houten VM, van den Brekel MW, Denkers F, Colnot DR, Westerga J, van Diest PJ, Snow GB and Brakenhoff RH: Molecular diagnosis of head and neck cancer. Recent Results Cancer Res 157: 90-106, 2000.

7. Tabor M, Brakenhoff R, van Houten VMM, Kummer JA, Snel MH, Snijders PJF, Snow GB, Leemans CR and Braakhuis BJM: Persistence of genetically altered fields in head and neck cancer patients: biological and clinical implications. Clin Cancer Res 7: 1523-1532, 2001.

8. Goldenberg D, Harden S, Masayesva BG, Ha P, Benoit N, Westra WH, Koch WM, Sidransky D and Califano JA: Intraoperative molecular margin analysis in head and neck cancer. Arch Otolaryngol Head Neck Surg 130: 39-44, 2004.

9. Simon C, Koitschev A and Plinkert PK: Gibt es tumorbiologische Besonderheiten, die ein bevorzugtes Auftreten von Rezidiven bei Kopf-Hals-Tumoren begünstigen: Tumorinvasion 'revisited' Laryngorhinootologie 86: 172-175, 2007.

10. Mao L, El-Naggar AK, Fan Y-H, Lee JS, Lippman SM, Kayser S, Lotan R and Hong WK: Telomerase activity in head and neck squamous cell carcinoma and adjacent tissues. Cancer Res 56: 5600-5604, 1996.

11. Patel MM, Patel DD, Parekh LJ, Raval GN, Rawal RM, Bhatavdekar JM, Patel BP and Patel PS: Evaluation of telomerase activation in head and neck cancer. Oral Oncol 35: 510-515, 1999.

12. Dhaene K, van Marck E and Parwaresch R: Telomeres, telomerase and cancer: an up-date. Virchows Arch 437: 1-16, 2000.

13. Fabricius E-M, Gurr U and Wildner G-P: Telomerase activity levels in the surgical margin and tumour distant tissue of the squamous cell carcinoma of the head-and-neck. Anal Cell Pathol 24: 25-39, 2002.

14. Gurr U: Der Nachweis der Telomeraseaktivierung in Tumorgeweben und dem Tumor benachbarten Geweben von Plattenepithelkarzinomen im Kopf-Hals-Bereich. Dissertation der medizinischen Fakultät der Humboldt-Universität Berlin, pp1-106, 2003.

15. Fabricius E-M: Molecular mechanisms of basal cell and squamous cell carinomas. In: The Role of Telomerase for Cancerogenesis of Basal Cell and Squamous Cell Carcinomas. Landes Bioscience and Springer Science and Bisness Media Inc., New York, pp115-133, 2006.

16. Kim N, Piatyszek M, Prowse K, Harley C, West M, Ho P, Coviello G, Wright W, Weinrich S and Shay J: Specific association of human telomerase activity with immortal cells and cancer. Science 266: 2011-2015, 1994

17. Hiyama E, Hiyama K, Yokoyama T and Shay JW: Immunohistochemical detection of telomerase (hTERT) protein in human cancer tissues and a subset of cells in normal tissues. Neoplasia 3: 17-26, 2001

18. Poremba C, Hero B, Heine B, Scheel C, Schaefer K-L, Christiansen H, Berthold F, Kneif S, Stein H, Juergens H, Boecker W and Dockhorn-Dworniczak B: Telomerase is a strong indicator for assessing the proneness to progression in neuroblastomas. Med Pediatr Oncol 35: 651-655, 2000

19. Poremba C, Scheel C, Hero B, Christiansen H, Schaefer KL, Nakayama J, Berthold F, Juergens H, Boecker W and DockhornDworniczak B: Telomerase activity and telomerase subunits gene expression patterns in neuroblastoma: a molecular and immunohistochemical study establishing prognostic tools for fresh-frozen and paraffin-embedded tissues. J Clin Oncol 18: 2582-2592, 2000

20. Poremba C, Heine B, Diallo R, Heinecke A, Wai D, Schaefer K-L, Braun Y, Schuck A, Lanvers C, Bànkfalvi Â, Kneif S, Torhorst J, Zuber M, Köchli OR, Mross F, Dieterich H, Sauter G, Stein H, Fogt $\mathrm{F}$ and Boecker W: Telomerase as a prognostic marker in breast cancer: high-throughput tissue microarray analysis of hTERT and hTR. J Pathol 198: 181-189, 2002.

21. Yan P, Benhattar J, Seelentag W, Stehle JC and Bosman FT: Immunohistochemical localization of hTERT protein in human tissues. Histochem Cell Biol 121: 391-397, 2004.
22. Park HR, Min SK, Cho HD, Kim KH, Shin HS and Park YE: Expression profiles of p63, p53, surviving, and hTERT in skin tumors. J Cutan Pathol 31: 544-549, 2004.

23. Wu YL, Dudognon C, Nguyen E, Hillion J, Pendino F, Tarkanyi I, Aradi J, Lanotte M, Tong JH, Chen GQ and Segal-Bendirdjian E: Immunodetection of human telomerase reverse-transcriptase (hTERT) re-appraised: nucleolin and telomerase cross paths. J Cell Sci 119: 2797-2806, 2006.

24. Wittekind Ch, Meyer HJ and Bootz F (eds): TNM Klassifikation maligner Tumoren. UICC International Union Against Cancer. 6. Aufl. Korr. Nachdruck. Kopf- und Halstumoren, pp19-52, 2005.

25. Cordell JL, Falini B, Erber WN, Ghosh AK, Abdulaziz Z, MacDonald S, Pulford KAF, Stein H and Mason DY: Immunoenzymatic labeling of monoclonal antibodies using immune complexes of alkaline phosphatase and monoclonal anti-alkaline phosphatase (APAAP complexes). J Histochem Cytochem 32: 219-229, 1984

26. Fabricius E-M, Langford A, Bier J, Hell B, Wildner G-P and Blümcke S: Immunohistochemical characterization of $\mathrm{E} 48$ and CD44-v6 expression in head and neck carcinomas. Cancer J 10: 325-330, 1997.

27. Fabricius E-M, Guschmann M, Wildner G, Langford A, Hell B and Bier J: Divergent immunohistochemical E48 and CD44-v6 antigen expression patterns between lymph node metastases and primary squamous cell carcinomas in the head and neck region. Cancer J 11: 325-330, 1998.

28. Fabricius E-M, Guschmann M, Langford A, Hell B and Bier J: Immunhistochemical assessment of the tumour-associated epitopes CD44v6 and E48 in tumour-free lymph nodes from patients with squamous cell carcinoma in the head-neck region. Anal Cell Pathol 20: 115-129, 2000

29. Remmele W, Hildebrand U, Hienz HA, Klein P-J, Vierbuchen M, Behnken LJ, Heicke B and Scheidt E: Comparative histological, histochemical, immunohistochemical and biochemical studies on oestrogen receptors, lectin receptors, and Barr bodies in human breast cancer. Virchows Arch A 409: 127-147, 1986.

30. Remmele W and Stegner HE: Vorschlag zur einheitlichen Definition eines immunreaktiven Score (IRE) für den immunohistochemischen Östrogenrezeptor-Nachweis (ER-ICA) im Mammagewebe. Pathologie 8: 138-140, 1987.

31. Alpha Diagnostics International (USA): Demonstration by antibody specificity of antigen (peptide/protein) blocking: 1, 1996.

32. Abcam (USA): Blocking with immunizing peptide (BL) protocol. $1,2006$.

33. Frost M, Bobak J, Gianani R, Kim N, Weinrich S, Spalding D, Cass L, Thompson L, Enomoto T, Uribe-Lopez D and Shroyer K: Localization of telomerase hTERT protein and hTR in benign mucosa, dysplasia, and squamous cell carcinoma of the cervix. Am J Clin Pathol 114: 726-734, 2000.

34. Sachs L: Angewandte Statistik - Anwendung statistischer Methoden. 11. Auflage Springer Verlag, Berlin, Heidelberg, p889, 2004.

35. Diehl JM and Staufenbiel T: Statistik mit SPSS für Windows Version 15. Verlag Dietmar Klotz, Eschborn, p720, 2007.

36. Kolquist K, Ellisen L, Counter C, Meyerson M, Tan L, Weinberg R, Haber D and Gerald W: Expression of TERT in early premalignant lesions and a subset of cells in normal tissues. Nat Genet 19: 182-186, 1998.

37. Park T, Riethdorf S, Riethdorf L, Löning T and Jänicke F: Differential telomerase activity, expression of the telomerase catalytic sub-unit and telomerase-RNA in ovarian tumors. Int J Cancer 84: 426-431, 1999.

38. Chou S, Chen C, Harn H, Chen C and Liu Y: In situ detection of hTERT mRNA relates to Ki-67 labeling index in papillary thyroid carcinoma. J Surg Res 99: 75-83, 2001

39. Kim H-R, Christensen R, Park N-H, Sapp P, Kang M and Park N-H: Elevated expression of hTERT is associated with dysplastic cell transformation during human oral carcinogenesis in situ. Clin Cancer Res 7: 3079-3086, 2001.

40. Dhaene K, Wauters J, Weyn B, Timmermans J and van Marck E: Expression profile of telomerase subunits in human pleural mesothelioma. J Pathol 190: 80-85, 2000.

41. Tahara H, Yasui W, Tahara E, Fujimoto J, Ito K, Tamai K, Nakayama J, Ishikawa F, Tahara $E$ and Ide T: Immunohistochemical detection of human telomerase catalytic component, hTERT, in human colorectal tumor and non-tumor tissue sections. Oncogene 18: 1561-1567, 1999. 
42. Kawakami Y, Kitamoto M, Nakanishi T, Yasui W, Tahara E, Nakayama J, Ishikawa F, Tahara H, Ide T and Kajiyama G: Immunohistochemical detection of human telomerase reverse transcriptase in human liver tissues. Oncogene 19: 3888-3893, 2000.

43. Wada H, Enomoto T, Yoshino K, Ozaki K, Kurachi H, Nomura T, Murata Y, Kim N, Weinrich S, Lea-Chou E, Lopez-Uribe D and Shroyer K: Immunohistochemical localization of telomerase hTERT protein and analysis of clonality in multifocal vulvar intraepithelial neoplasia. Am J Clin Pathol 114: 371-379, 2000.

44. Lehner R, Bobak J, Kim N, Shroyer A and Shroyer K: Localization of telomerase hTERT protein and survivin in placenta: relation to placental development and hydatidiform mole. Obstet Gynecol 97: 965-970, 2001

45. Lehner R, Enomoto T, McGregor J, Shroyer A, Haugan B, Pugazhenthi U and Shroyer K: Quantitative analysis of telomerase hTERT mRNA and telomerase activity in endometrioid adenocarcinoma and in normal endometrium. Gynecol Oncol 84: $120-125,2002$

46. Yang S, Zhang B, Wang J, Liao S, Han J, Wei J and Hou L: Monoclonal antibodies against human telomerase reverse transcriptase (hTERT): preparation, characterization, and application. Hybridoma 20: 249-255, 2001.

47. Nguyen DC, Parsa B, Close A, Magnusson B, Crowe DL and Sinha UK: Overexpression of cell cycle regulatory proteins correlates with advanced tumor stage in head and neck squamous cell carcinomas. Int J Oncol 22: 1285-1290, 2003.

48. Kumar SK, Zain RB, Ismail SM and Cheong SC: Human telomerase reverse transcriptase expression in oral carcinogenesis a preliminary report. J Exp Clin Cancer Res 24: 639-646, 2005.

49. Luzar B, Poljak M and Gale N: Telomerase catalytic subunit in laryngeal carcinogenesis - an immunohistochemical study. Mod Pathol 18: 406-411, 2005

50. Chen HH, Yu CH, Wang JT, Liu BY, Wang YP, Sun A, Tsai TC and Chiang CP: Expression of human telomerase reverse transcriptase (hTERT) protein is significantly associated with the progression, recurrence and prognosis of oral squamous cell carcinoma in Taiwan. Oral Oncol 43: 122-129, 2007.

51. Freier K, Pungs S, Flechtenmacher C, Bosch FX, Lichter P, Joos $\mathrm{S}$ and Hofele C: Frequent high telomerase reverse transcriptase expression in primary oral squamous cell carcinoma. J Oral Pathol Med 36: 267-272, 2007.

52. Gonzalez-Quevedo R, De Juan C, Massa M, Sanchez-Pernaute A, Torres A, Balibrea J, Benito M and Iniesta P: Detection of telomerase activity in human carcinomas using a trap-ELISA method: correlation with hTR and hTERT expression. Int J Oncol 16: 623-628, 2000

53. Fujimoto S, Kamata N, Yokoyama K, Ueda N, Satomura K, Hayashi E and Nagayama M: Expression of telomerase components in oral keratinocytes and squamous cell carcinomas. Oral Oncol 37: 132-140, 2001.

54. Hoang-Vu C, Boltze C, Gimm O, Poremba C, DockhornDworniczak B, Kohrle J, Rath FW and Dralle H: Expression of telomerase genes in thyroid carcinoma. Int J Oncol 21: 265-272, 2002.

55. Malaska J, Kunicka Z, Borsky M, Sklenickova M, Novotna M, Fajkusova L, Zaloudik J and Fajkus J: Telomerase as a diagnostic and predictive marker in colorectal carcinoma. Neoplasma 51: 90-96, 2004.

56. Kyo S, Masutomi K, Maida Y, Kanaya T, Yatabe N, Nakamura M, Tanaka M, Takarada M, Sugawara I, Murakami S, Taira $\mathrm{T}$ and Inoue M: Significance of immunological detection of human telomerase reverse transcriptase: re-evaluation of expression and localization of human telomerase reverse transcriptase. Am J Pathol 163: 859-867, 2003.

57. Yan P, Coindre JM, Benhattar J, Bosman FT and Guillou L: Telomerase activity and human telomerase reverse transcriptase mRNA expression in soft tissue tumors: correlation with grade, histology, and proliferative activity. Cancer Res 59: 3166-3170, 1999.

58. Shay J, Zou Y, Hiyama E and Wright W: Telomerase and cancer. Hum Mol Genet 10: 677-685, 2001

59. Etheridge K, Banik S, Armbruster BZY, Tern R, Terns M and Counter $\mathrm{C}$ : The nucleolar localization domain of the catalytic subunit of human telomerase. J Biol Chem 277: 24764-24770, 2002.

60. Wu A, Ichihashi M and Ueda M: Correlation of the expression of human telomerase subunits with telomerase activity in normal skin and skin tumors. Cancer 86: 2038-2044, 1999.
61. Pannone G, De Maria S, Zamparese R, Metafora S, Serpico R, Morelli F, Rubini C, Farina E, Carteni M, Staibano S, De Rosa G, Lo Muzio L and Bufo P: Prognostic value of human telomerase reverse transcriptase gene expression in oral carcinogenesis. Int J Oncol 30: 1349-1357, 2007.

62. Wei R and Younes M: Immunohistochemical detection of telomerase reverse transcriptase in colorectal adenocarcinoma and benign colonic mucosa. Hum Pathol 33: 693-696, 2002.

63. Lam AK, Ong K and Ho YH: hTERT expression in colorectal adenocarcinoma: correlations with p21, p53 expressions and clinicopathological features. Int J Colorectal Dis 23: 587-594, 2008.

64. Lantuejoul S, Soria JC, Moro-Sibilot D, Morat L, Veyrenc S, Lorimier P, Brichon PY, Sabatier L, Brambilla C and Brambilla E: Differential expression of telomerase reverse transcriptase (hTERT) in lung tumours. Br J Cancer 90: 1222-1229, 2004.

65. Toomey D, Smyth G, Condron C, Kay E, Conroy R, Foley D, Hong C, Hogan B, Toner S, McCormick P, Broe P, Kelly C and Bouchier-Haynes D: Immune function, telomerase, and angiogenesis in patients with primary, operable non-small cell lung carcinoma. Tumor size and lymph node status remain the most important prognostic features. Cancer 92: 2648-2657, 2001.

66. Tabori U, Wong V, Ma J, Shago M, Alon N, Rutka J, Bouffet E, Bartels U, Malkin D and Hawkins C: Telomere maintenance and dysfunction predict recurrence in paediatric ependymoma. Br J Cancer 99: 1129-1135, 2008.

67. Elkak AE, Meligonis G, Salhab M, Mitchell B, Blake JR, Newbold RF and Mokbel K: hTERT protein expression is independent of clinicopathological parameters and c-Myc protein expression in human breast cancer. J Carcinog 4: 17-22, 2005.

68. Mavrommatis J, Mylona E, Gakiopoulou H, Stravodimos C, Zervas A, Giannopoulos A and Nakopoulou L: Nuclear hTERT immunohistochemical expression is associated with survival of patients with urothelial bladder cancer. Anticancer Res 25: 3109-3116, 2005

69. Volpi A, Bravaccini S, Medri L, Cerasoli S, Gaudio M and Amadori D: Usefulness of immunological detection of the human telomerase reverse transcriptase. Cell Oncol 27: 347-353, 2005.

70. Taylor CR, Shi SR, Chen C, Young L, Yang C and Cote RJ: Comparative study of antigen retrieval heating methods: microwave, microwave and pressure cooker, autoclave, and steamer. Biotech Histochem 71: 263-270, 1996.

71. DakoCytomation: Handbuch Immunchemische Färbemethoden. Boenisch T (ed). 3. Aufl. ed, pp1-86, 2003

72. Kleinschmidt K: Inaugural-Dissertation zur Erlangung des Grades einer Doktorin der Veterinärmedizin (Dr. med. vet.) durch die Tierärztliche Hochschule Hannover: Untersuchung von Endostatin freisetzenden Stammzellimplantaten zur Behandlung des Glioblastoms im Rattenmodell, pp1-207, 2006.

73. Hiyama $\mathrm{E}$ and Hiyama K: Telomerase as tumor marker. Cancer Lett 194: 221-233, 2003.

74. Hiyama E and Hiyama K: Telomerase detection in the diagnosis and prognosis of cancer. Cytotechnology 45: 61-74, 2004.

75. Miyazu YM, Miyazawa T, Hiyama K, Kurimoto N, Iwamoto Y, Matsuura H, Kanoh K, Kohno N, Nishiyama M and Hiyama E: Telomerase expression in noncancerous bronchial epithelia is a possible marker of early development of lung cancer. Cancer Res 65: 9623-9627, 2005.

76. Hashimoto Y, Murakami Y, Uemura K, Hayashidani Y, Sudo T, Ohge H, Fukuda E, Sueda T and Hiyama E: Detection of human telomerase reverse transcriptase (hTERT) expression in tissue and pancreatic juice from pancreatic cancer. Surgery 143: 113-125, 2008.

77. Ohkoudo M, Sawa H, Shiina Y, Sato H, Kamata K, Iijima J, Yamamoto H, Fujii M and Saito I: Morphometrical analysis of nucleolin immunohistochemistry in meningiomas. Acta Neuropathol (Berl) 92: 1-7, 1996.

78. Bettendorf O, Heine B, Kneif S, Eltze E, Semjonow A, Herbst H, Stein H, Bocker W and Poremba C: Expression-patterns of the RNA component (hTR) and the catalytic subunit (hTERT) of human telomerase in nonneoplastic prostate tissue, prostatic intraepithelial neoplasia, and prostate cancer. Prostate 55: 99-104, 2003.

79. Seo EJ, Kim HJ, Lee CJ, Kang HT and Hwang ES: The role of HPV oncoproteins and cellular factors in maintenance of hTERT expression in cervical carcinoma cell. Gynecol Oncol 94: 40-47, 2004. 
80. Boltze C, Mundschenk J, Unger N, Schneider-Stock R, Peters B, Mawrin C, Hoang-Vu C, Roessner A and Lehnert H: Expression profile of the telomeric complex discriminates between benign and malignant pheochromocytoma. J Clin Endocrinol Metab 88: 4280-4286, 2003.

81. Forsyth R, De Boeck G, Bekaert S, De Meyer T, Taminiau A, Uyttendaele D, Roels H, Praet M and Hogendoorn P: Telomere biology in giant cell tumour of bone. J Pathol 214: 555-563, 2008.

82. Masutomi K, Yu E, Khurts S, Ben-Porath I, Currier J, Metz G, Brooks M, Kaneko S, Murakami S, De Caprio J, Weinberg R, Stewart S and Hahn W: Telomerase maintains telomere structure in normal human cells. Cell 114: 241-253, 2003.

83. Lin J, Jin R, Zhang B, Yang PX, Chen H, Bai YX, Xie Y, Huang $\mathrm{C}$ and Huang $\mathrm{J}$ : Characterization of a novel effect of hPinX1 on hTERT nucleolar localization. Biochem Biophys Res Commun 353: 946-952, 2007.

84. Tomlinson RL, Ziegler TD, Supakorndej T, Terns RM and Terns MP: Cell cycle-regulated trafficking of human telomerase to telomeres. Mol Biol Cell 17: 955-965, 2006.

85. Nakamura K, Kaneko T, Yamashita Y, Hasegawa H, Katoh H, Ichikawa A and Negishi M: Immunocytochemical localization of prostaglandin EP3 receptor in the rat hypothalamus. Neurosci Lett 260: 117-120, 1999.

86. Klinck R, Serup P, Madsen OD and Jørgensen MC: Specificity of four monoclonal anti-NKx6-1 antibodies. J Histochem Cytochem 56: 415-424, 2008.

87. Wong JM, Kusdra L and Collins K: Subnuclear shuttling of human telomerase induced by transformation and DNA damage. Nat Cell Biol 4: 731-736, 2002.

88. Zhu Y, Tomlinson RL, Lukowiak AA, Terns RM and Terns MP: Telomerase RNA accumulated in cajal bodies in human cancer cells. Mol Biol Cell 15: 81-90, 2004

89. Yang Y, Chen Y, Zhang C, Huang H and Weissman SM: Nucleolar localization of hTERT protein is associated with telomerase function. Exp Cell Res 277: 201-209, 2002.

90. Lin J, Jin R, Zhang B, Chen H, Bai YX, Yang PX, Han SW, Xie YH, Huang PT, Huang C and Huang JJ: Nucleolar localization of TERT is unrelated to telomerase function in human cells. J Cell Sci 121: 2169-2176, 2008.

91. Khurts S, Masutomi K, Delgermaa L, Arai K, Oishi N, Mizuno H, Hayashi N, Hahn WC and Murakami S: Nucleolin interacts with telomerase. J Biol Chem 279: 51508-51515, 2004.

92. Ginisty H, Sicard H, Roger B and Bouvet P: Structure and functions of nucleolin. J Cell Sci 112: 761-772, 1999.

93. Yajima Y, Noma H, Furuya Y, Nomura T, Yamauchi T, Kasahara K, Hatada K and Takano M: Quantification of telomerase activity of regions unstained with iodine solution that surround oral squamous cell carcinoma. Oral Oncol 40: 314-320, 2004.

94. Hiyama K, Hirai Y, Kyoizumi S, Akiyama M, Hiyama E, Piatyszek M-A, Shay J-W, Ishioka S and Yamakido M: Activation of telomerase in human lymphocytes and hematopoietic progenitor cells. J Immunol 155: 3711-3715, 1995.

95. Yamada O, Motoji T and Mizoguchi H: Up-regulation of telomerase activity in human lymphocytes. Biochim Biophys Acta 1314: 260-266, 1996.

96. Counter C-M, Gupta J, Harley C-B, Leber B and Bacchetti S: Telomerase activity in normal leukocytes and in hematologic malignancies. Blood 85: 2315-2320, 1995.
97. Broccoli D, Young JW and De Lange T: Telomerase activity in normal and malignant hematopoietic cells. Proc Natl Acad Sci USA 92: 9082-9086, 1995.

98. Bodnar AG, Kim NW, Effros RB and Chiu CP: Mechanism of telomerase induction during $\mathrm{T}$ cell activation. Exp Cell Res 228: 58-64, 1996.

99. Shay JW and Wright WE: Telomerase activity in human cancer. Curr Opin Oncol 8: 66-71, 1996.

100. Guo M, Rabin B, Johnson J and Paradis I: Lymphocytic phenotypes at tumor margins in patients with head and neck cancer. Head Neck Surg 9: 265-271, 1987.

101. Kannan S, Tahara H, Yokozaki H, Mathew B, Nalinakumari K, Nair $\mathrm{M}$ and Tahara E: Telomerase activity in premalignant and malignant lesions of human oral mucosa. Cancer Epidemiol Biomarkers Prev 6: 413-420, 1997.

102. Takes RP: Staging of the neck in patients with head and neck squamous cell cancer: imaging techniques and biomarkers. Oral Oncol 40: 656-667, 2004.

103. Feinmesser M, Okon E, Schwartz A, Kaganovsky E, Hardy B, Aminov E, Nageris B, Sulkes J and Feinmesser R: Histologic and immunohistochemical characterization of tumor and inflammatory infiltrates in oral squamous cell carcinomas treated with local multikine immunotherapy: the macrophage at the front line. Eur Arch Otorhinolaryngol 261: 359-368, 2004.

104. Hohaus S, Cavallo S, Bellacosa A, Genuardi M, Galli J, Cadoni G, Almadori G, Lauriola L, Litwin S, Maurizi M and Neri G: Telomerase activity in human laryngeal squamous cell carcinomas. Clin Cancer Res 2: 1895-1900, 1996.

105. Eissa S, Kenawy G, Moteleb FA, El-Magkhzangy AN and Nassar M: Real-time PCR hTERT mRNA pattern in tumor core, edge, resection margin, and lymph nodes in laryngeal tumors: relation to proliferative index and impact on prognosis. Clin Biochem 28: 873-878, 2005.

106. Xiao Y, Gao X, Gannot G, Emmert-Buck MR, Srivastava S, Wagner PD, Amos MD and Barker PE: Quantitation of HER2 and telomerase biomarkers in solid tumors with $\operatorname{IgY}$ antibodies and nanocrystal detection. Int J Cancer 122: 2178-2186, 2008.

107. Lantuejoul S, Salon C, Soria J-C and Brambilla E: Mini review: telomerase expression in lung preneoplasia and neoplasia. Int $\mathrm{J}$ Cancer 120: 1835-1841, 2007.

108. Burnworth B, Arendt S, Muffler S, Steinkraus V, Brocker EB, Birek C, Hartschuh W, Jauch A and Boukamp P: The multistep process of human skin carcinogenesis: a role for $\mathrm{p} 53$, cyclin D1, hTERT, p16, and TSP-1. Eur J Cell Biol 86: 763-780, 2007.

109. Cassaro M, Rugge M, Tieppo C, Giacomelli L, Velo D, Nitti D and Farinati F: Indefinite for non-invasive neoplasia lesions in gastric intestinal metaplasia: the immunophenotype. J Clin Pathol 60: 615-621, 2007.

110. Olsen SH, Su LD, Thomas D and Fullen DR: Telomerase expression in sebaceous lesions of the skin. J Cutan Pathol 34: 386-391, 2007

111.Zendehrokh N, Rehnberg J and Dejmek A: Comparison of NCLhTERT antibody reactivity and telomere repeat amplification protocol in situ in effusions. Acta Cytol 51: 886-892, 2007.

112. Yang CH, Hung WC, Wang SL, Kang WY, Chen WT, Huang YC, Su YC and Chai CY: Immunoexpression and prognostic role of hTERT and cyclin D1 in urothelial carcinoma. APMIS 116: 309-316, 2008. 